IZA DP No. 7698

Steady-State Labor Supply Elasticities: A Survey

Olivier Bargain

Andreas Peichl

October 2013

Forschungsinstitut zur Zukunft der Arbeit Institute for the Study of Labor 


\title{
Steady-State Labor Supply Elasticities: A Survey
}

\author{
Olivier Bargain \\ Aix-Marseille University, CNRS, EHESS \\ and IZA
}

Andreas Peichl

ZEW, University of Mannheim, CESifo and IZA

Discussion Paper No. 7698

October 2013

\author{
IZA \\ P.O. Box 7240 \\ 53072 Bonn \\ Germany \\ Phone: $+49-228-3894-0$ \\ Fax: +49-228-3894-180 \\ E-mail: iza@iza.org
}

Any opinions expressed here are those of the author(s) and not those of IZA. Research published in this series may include views on policy, but the institute itself takes no institutional policy positions. The IZA research network is committed to the IZA Guiding Principles of Research Integrity.

The Institute for the Study of Labor (IZA) in Bonn is a local and virtual international research center and a place of communication between science, politics and business. IZA is an independent nonprofit organization supported by Deutsche Post Foundation. The center is associated with the University of Bonn and offers a stimulating research environment through its international network, workshops and conferences, data service, project support, research visits and doctoral program. IZA engages in (i) original and internationally competitive research in all fields of labor economics, (ii) development of policy concepts, and (iii) dissemination of research results and concepts to the interested public.

IZA Discussion Papers often represent preliminary work and are circulated to encourage discussion. Citation of such a paper should account for its provisional character. A revised version may be available directly from the author. 
IZA Discussion Paper No. 7698

October 2013

\section{ABSTRACT \\ Steady-State Labor Supply Elasticities: A Survey*}

Previous reviews of static labor supply estimations concentrate mainly on the evidence from the 1980s and 1990s, Anglo-Saxon countries and early generations of labor sup- ply modeling. This paper provides a fresh characterization of steady-state labor supply elasticities for Western Europe and the US. We also investigate the relative contribution of different methodological choices in explaining the large variation in elasticity size observed across studies. While some recent studies show that genuine preference heterogeneity across countries explains only a modest share of this variation (Bargain et al., 2013), we focus here on time changes and estimation methods as key contributors of the differences across studies. Both factors can explain larger elasticities in older studies (i.e. an increase in female labor market attachment over time and a switch from the Hausman estimation approach to discrete-choice models with tax-benefit simulations). Meta-analysis evidence suggests that smaller elasticities in the recent period may be due to the time factor, i.e. a likely change in work preferences, both in the US and in Europe.

JEL Classification: $\quad$ C25, C52, H31, J22

Keywords: household labor supply, elasticity, taxation, Europe, US

Corresponding author:

Olivier Bargain

Aix Marseille University and GREQAM

Chateau Lafarge

Route des Milles

13290 Aix-en-Provence (Les Milles)

France

E-mail: olivier.bargain@univ-amu.fr

${ }^{*}$ The usual disclaimer applies. 


\section{Introduction}

Static models of labor supply are very useful to predict the effect of tax-benefit policy reforms ex ante, to calibrate an optimal tax model or more generally to provide an order of magnitude of the short-term response to financial incentives. Responsiveness is often summarized by a measure of what Chetty et al. (2011) refer to as "steady-state elasticities", i.e. wage or income elasticities of labor market participation or worked hours stemming from a static framework. In principle, these estimates should also provide some information on international differences in labor supply responses. However, the variation in magnitude of labor supply elasticities found in the literature is huge (see Evers et al., 2008) and there is little agreement among economists on the elasticity size that should be used in economic policy analyses (Fuchs et al., 1998). In Bargain et al. (2013), we show that only a small share of this variation is driven by genuine differences in work preference across countries. In fact, other factors account for the large difference in elasticity size observed across studies and notably the period of investigation, which may reflect changes in work preferences over time, and modeling choices (estimation method and model specification). To understand the relative contribution of these two factors, a careful and comprehensive survey of the literature on steady-state elasticities is required, which we undertake in the present paper.

Our survey substantially completes previous reviews on static labor supply models. Handbook studies written in the 1980s mainly focus on estimations using the continuous labor supply model of Hausman (1981) and provide evidence essentially for individuals in couples (Hausman, 1985b, Pencavel, 1986, for married men, Killingsworth and Heckman, 1986, for married women). More recent surveys incorporate some evidence from recent methods (see Blundell and MaCurdy, 1999; Meghir and Phillips, 2008) or focus on life-cycle models (Keane, 2011; Keane and Rogerson, 2012; McClelland and Mok, 2012). Yet, most of these surveys mainly summarize the available evidence for the US and the UK. Evers et al. (2008) suggest a meta-analysis based on estimates for different Western countries, focusing essentially on those obtained with the traditional Hausman approach. In the present paper, we complete this literature by providing a wider and more comprehensive comparison of international evidence on steady-state labor supply elasticities. We collect old and recent estimates for Europe and the US, covering the studies based on the Hausman method, more recent ones based on discrete-choice structural models and, when available, estimates drawn from natural experiments. ${ }^{1}$ We acknowledge that differences across studies can be driven by dif-

\footnotetext{
${ }^{1}$ We focus on labor supply decisions (hours and participation). Hence, we ignore the other margins that are captured in the literature on the elasticity of taxable income (see Meghir and Phillips, 2008, and Saez et al., 2012, for surveys). Arguably, these other margins partly relate to responses not directly pertaining to productive behavior, like tax evasion and tax optimization. In this regard, hours of work still constitute an interesting benchmark. Another margin is work effort that may affect wage rates. In the short run, however, hours and participation are the only variables of adjustment for a large majority of workers. We also leave aside the macroeconomic literature, in which elasticities are often obtained by calibration of general equilibrium models. These elasticities are much larger than in microeconomic studies (e.g., Prescott,
} 
ferences in work preferences across countries or over time and by methodological differences (data and selection, estimation method and model specification). We compare 282 elasticity estimates resulting from 92 studies, including 156 wage elasticities for individuals in couples, 70 wage elasticities for single individuals and lone parents and 56 income elasticities.

Our results go as follows. First, we broadly confirm the modest consensus reached in the literature, establishing that own-wage elasticities are largest for married women, smaller for men. Recent studies confirm these findings, but not the negative elasticities for men as sometimes found in older studies. Estimates for men are generally positive and small, with some exceptions (for instance Ireland and some German studies). Some of the studies for the US and the UK, but not all, point to substantial elasticities for single parents while estimates for childless singles are usually missing. Second, for each demographic group, we observe a very large variance in estimates across all available studies. This is partly due to the use of the Hausman approach, which seems to overstate elasticities compared to what is found with more recent approaches and notably the use of discrete choice models. The other main factor behind different estimates relates to time periods. For the US, we corroborate the findings of Heim (2007) and Blau and Kahn (2007), who show, using a uniform approach for different periods, that married women's wage-elasticities decline over time. Given that the use of the Hausman method coincides with older studies, it is nonetheless difficult to disentangle the two factors. Restricting our meta-analysis to years of common support, we find suggestive evidence in favor of the hypothesis of a time decline in elasticities for both the US and Europe. This means that the result of Heim, Blau and Kahn might be generalized to EU countries and that in both regions, a more stable attachment of women to the labor market is responsible for more modest labor supply responses to wage variation. There is no clear evidence that estimation methods matter - in fact, estimates from discrete choice models are missing for the long period and should be the subject of future research. The rest of the paper is organized as follows. In Section 2, we describe the various empirical approaches to estimate static labor supply elasticities. Section 3 reports and analyzes survey results. Section 4 concludes.

\section{Methods: A Critical Review}

The principal object of examination in this study is the size of wage and income elasticities stemming from static labor supply models. Responsiveness to financial incentives in these models has been identified in various ways. There is no generally agreed-upon standard estimation approach and we provide here a brief critical review. A more technical and 2004). Several reasons have been suggested for this: the use of representative agents and difficulties around aggregation theory when heterogeneity matters (see Blanchard, 2006), the existence of a social multiplier whereby the utility from not working is increasing in the number of people who do not work (see Alesina et al., 2005), and factors related to the timing and the nature of labor supply adjustments (Chetty et al., 2011). 
comprehensive presentation of these methods and their identification strategies are provided in Blundell and MaCurdy (1999) and Blundell et al. (2007).

Traditional estimation techniques rely on some functional specification of a labor supply function and the underlying consumption-leisure preferences. Estimation is then made through local linearization of the budget constraint, accounting for the fact that after-tax wages depend on the labor supply choice (Hall, 1973) or using more comprehensive techniques (Hausman, 1981,1985a, 1985b). The approach relies on cross-section variation in working hours and in the two main covariates, i.e. the after-tax wage and the virtual income (i.e. the intercept of the linearized budget constraint). As a result, the main identification issue is the endogeneity of wages and unearned income, which can be seen as an omitted variable problem. Indeed, wages may be endogenous because unobservables affecting preferences for work, e.g., being a hard-working person, may well be correlated with unobservables affecting productivity and hence wages. Unearned income may be endogenous for similar reasons, i.e. individuals who work harder because of unobserved preferences for work are also likely to have accumulated more assets; if unearned income also represents income from the spouse, positive assortative mating could imply that hard working individuals will tend to marry similar persons, another reason for the endogeneity issue. Hence, estimates obtained from cross-sectional variation in wages and nonlabor income across individuals are potentially biased. Instrumental variables methods have been suggested and the validity of the Hausman approach hinges on whether the exclusion assumptions of the economic model hold. Also, estimates are potentially contaminated by measurement errors from the division bias (cf. Ziliak and Kniesner, 1999). In addition, a series of practical difficulties limit the application of the method. First, relying on tangency conditions, the Hausman model is mainly restricted to the case of piecewise linear and convex budget sets, i.e., a partial representation of the effect of tax-benefit policies on household budget constraints. This limitation applies equally to generalizations of the technique to non-parametric estimations (Blomquist and Newey, 2002). To account for non-convexities, as in Hausman (1985b) and Hausman and Ruud (1984), labor supply must be specified parametrically together with the corresponding direct utility function, which implies rather restrictive forms for preferences (see the discussion in Van Soest and Das, 2001). ${ }^{2}$ Second, quasi-concavity of the utility function is implicitly imposed a priori. As discussed by MaCurdy et al. (1990) and MaCurdy (1992), the Hausman method thus requires global satisfaction of the Slutsky condition by the labor supply function for internal consistency of the model, an unnecessary behavioral restriction that may bias estimates (see a modern statement in Heim and Meyer, 2003, and Meghir and

\footnotetext{
${ }^{2}$ Another approach is the reconvexification of the budget set. For instance, to estimate the labor supply of married women on 1985 French data, Bourguignon and Magnac (1990) use the Hausman technique and eliminate minor non-convexities by replacing the budget set by its convex envelope. This approach is not possible for later years as the implementation of a minimum income scheme in 1988 has introduced high non-convexity in the budget constraint. Similar non-convexities arise in all countries with substantial meanstested transfers.
} 
Phillips, 2008). Third, the model makes it difficult to handle joint labor supply decisions within a couple or participation decisions. Instead of non-participation following simply from the corner solution of the model, fixed costs of work can be introduced, yet this additional source of non-convexity has to be dealt with and results seem to be very sensitive to the model specification (see the discussion in Bourguignon and Magnac, 1990).

Instead of estimating a labor supply function, the discrete choice approach is based on the concept of random utility maximization (see van Soest, 1995, or Hoynes, 1996, among others). Thus, it requires the explicit parameterization of consumption-leisure preferences, for utility to be evaluated at each discrete alternative. Tangency conditions need not be imposed and the model is in principle very general. Labor supply decisions are reduced to choosing among a discrete set of possibilities, e.g., inactivity, part-time and full-time. This solves several problems encountered with the Hausman method. In particular, discrete choice modeling includes non-participation as one of the options so that both extensive and intensive margins are directly estimated. The complete effect of the tax-benefit system is easily accounted for, even in the presence of non-convexities in budget sets. Work costs, which also create non-convexities, are dealt with relatively easily. Estimated as model parameters as in Callan et al. (2009) or Blundell et al. (2000), they usually improve the fit of these models as they account for the fact that very few observations exist with a small positive number of worked hours. Very few restrictions on preferences need to be imposed in discrete choice models, notably because fixed costs of work cannot be disentangled from preference parameters, so that it makes no sense to impose the convexity of preferences (see van Soest et al., 2002, Heim and Meyer, 2003, Bargain, 2009). The only restriction to the model is the imposition of increasing monotonicity in consumption, which seems a minimum requirement for meaningful interpretation and policy analysis. Joint labor supply decision for couples is a straightforward extension of the basic model in the discrete choice setting. Yet, many applications still treat husbands' working hours fixed at observed levels and focus on the labor supply of women, i.e. a male chauvinist model (e.g., Bargain, 2009; such treatment is typical in Hausman models, e.g. Killingsworth and Heckman, 1986). The implication of such separable treatment of spouses' labor supply choices is relatively unknown.

In the discrete choice approach, identification is mainly provided by nonlinearities, nonconvexities and discontinuities in the budget constraint due to tax-benefit rules (see the discussion in Blundell et al., 2007, and Bargain et al., 2013). Precisely, individuals with the same gross wage usually receive different net wages. Indeed, as they are characterized by different circumstances (different marital status, age, family compositions, home-ownership status, disability status) or levels of non-labor income, their effective tax schedules are different, i.e., different actual marginal tax rates or benefit withdrawal rates. Arguably, some of the conditioning characteristics (age, children) are also included as preference variables in the model so that identification is essentially parametric. In practice, some exclusion restrictions come naturally. Indeed, tax-benefit rules depend on characteristics which are 
much more detailed than usual taste-shifters (e.g. benefit rules depending on detailed geographical information while preferences are assumed to depend only on urban versus rural areas or on whether the household lives in the capital city). Additional, more convincing sources of exogenous variation are also used in some studies. Closer to the natural experiment method, these consist in time or regional variation in tax-benefit rules. For instance, in the US, variation in income tax rules or in the parameters of the Earned Income Tax Credit (EITC) across states is used in Eissa and Hoynes (2004) or Hoynes (1996). Time variation in tax-benefit rules also provide a better identification when policy reforms occur over the period under consideration, as discussed, e.g., in Bargain et al. (2013)

A third approach consists in using policy reforms explicitly in order to identify labor supply responses, without attempting to estimate a structural model (e.g., Eissa and Liebman, 1996). Natural experiments based on important tax-benefit reforms in the US and the UK have been extensively used to identify behavioral parameters (see the survey of Hotz and Scholz, 2003, for the US). For example, Eissa and Liebman (1996) use a differencein-difference approach to identify the impact of the EITC reforms on the labor supply of single mothers. They find compelling evidence that single mothers joined the labor market in response to increased financial incentives to work. Regarding identification, the definition of control groups might be an issue in difference-in-difference approaches. For instance, responses to EITC expansions affecting single mothers were evaluated using childless women as control group, which may not be ideal given different long-term trends in labor supply in the two groups (see Hotz and Scholz, 2003). ${ }^{3}$ Regression discontinuity (RD) is deemed better in this respect since the nature of individuals on both sides of the discontinuity is "as good as random" (cf. Lemieux and Milligan, 2008). Overall, much of the evidence is concentrated in studies from the US, Canada and the UK. There is less evidence for other countries and notably for continental Europe maybe because large reforms, creating exogenous variation in tax-benefit rules, were less available. Partly for this reason, structural models described above have been very much in use. ${ }^{4}$ The timing of response to policy reforms or policy discontinuity is unclear. Nonetheless, the implicit model that analysts have in mind when discussing the "next-morning" effect of the policy impact is often a static one (cf. Lemieux

\footnotetext{
${ }^{3}$ This issue is shared with the literature on the elasticity of taxable income, whereby results are sensitive to the type of reforms exploited for identification (Saez et al., 2012). Indeed, control groups definition follows from their income level, so that specific preferences are identified and results cannot be extrapolated. For instance, changes in tax rates (tax credits) identify the preferences of high (low) income groups, and may not be generalized to the whole population.

${ }^{4}$ Things are changing in the recent period. For France, for instance, some studies have recently used taxbenefit changes to evaluate the responsiveness of the labor force, including the introduction of a small tax credit (Stancanelli, 2008), time change in income tax schedule (Carbonnier, 2008), changes in the possibility to cumulate welfare payment for lone mothers and earnings (González, 2008), and age condition on children for a replacement income targeted at low-income mothers who opt for full-time childcare (Piketty, 1998). RD estimations using age conditions on the level of social assistance program are also used in Bargain and Doorley (2011), in a similar way as Lemieux and Milligan (2008) for Canada.
} 
and Milligan, 2008, or Bargain and Doorley, 2011). Reduced-form approaches, based on policy reforms or discontinuities, are increasingly used because natural experiments probably offer one of the most credible sources of identification, despite the limitations outlined above. In this way, it is important to compare estimates from these studies with those stemming from structural model estimations. Unfortunately, these studies do not systematically report wage elasticities. They rather report labor supply elasticities to benefit or tax rate changes. Thus, for comparability purposes, we could include only a few of them in the present survey. Also, the fact that actual reforms - notably welfare reforms in the US and the UK - typically affect couples or single women with children makes that very little evidence is available for other demographic groups, in particular for childless single individuals.

Finally, a few studies rely on long-term changes in wages as well as on observation grouping in order to address endogeneity and the problem of measurement error in hourly wages discussed above (Devereux, 2003, 2004). Blundell et al. (1998) also use tax-benefit policy variation over a long period to identify labor supply responses in the UK using a grouping IV estimator. Long-term variation may pose the problem of assuming that preferences remain stable in the long run, an issue which is rarely discussed. We include most of these studies, at least those for which estimates can be compared with other studies, in our survey.

\section{Static Labor Supply Elasticities: A Survey}

We present here existing evidence on labor supply elasticities for European couples (Table 1), European single individuals (Table 2) and all demographic groups in the US (Table 3). The reason for this classification is that US studies are more numerous (and, hence, deserve a particular focus) and sometimes consider several demographic groups simultaneously (e.g. Pencavel, 2002, Devereux, 2003). We separately report unconditional wage elasticities (total hour and participation responses) and income elasticities. Tables highlight methodological differences across studies and notably where elasticities stem from the estimation of continuous labor supply functions (the Hausman approach), from the estimation of discrete choice models, from grouped estimations or natural experiments. We can observe an overrepresentation of studies based on discrete choice models with taxation, as this method is increasingly used around the world to analyze the effect of fiscal and social policy reforms. We do not pretend to be fully exhaustive but nonetheless attempt to give a sense of the range of elasticities obtained in the vast literature for Europe and the US. Some studies do not report elasticities and unfortunately could not be included in our tables. This is the case with some studies using labor supply models (e.g., Hoynes, 1996, reports income elasticities but not wage elasticities) and more generally the case with studies using policy reforms as natural experiments, as indicated above (for instance Bingley and Walker, 1997, for the UK, or Eissa and Liebman, 1996, for the US). In addition to Tables 1-3, the analysis below is supported by graphics obtained using wage-elasticity estimates drawn from these tables. 


\subsection{Overview}

Figure 1 plots the distribution of wage-elasticity estimates by demographic group. The vertical axis reports the frequency (number of estimates). The first observation is that married women is the group with the largest number of available estimates. The second lesson from these graphs is that, in line with conventional wisdom, elasticities are largest among married women and single mothers, with mean values of .43 and .59 respectively. These groups also show much dispersion across available studies. While a majority of estimates for married women are found between 0 and .50, estimates for single mothers are far less numerous and more dispersed over a broad range of values. Married and single men (mean value: .12) and childless single women (mean value: .23) show much less variation and most estimates stand in a narrow range between 0 and .30. These conclusions do not change radically if we consider more specific types of elasticities, namely total hour elasticities or participation elasticities (detailed results available from the authors). We now discuss each demographic group specifically.

Married Women. Considering Tables 1 and 3, we observe much dispersion in estimates for married women. This is confirmed in Figure 2 (top left quadrant) where we plot the distribution of wage-elasticity estimates for each country. The black triangular cursors indicate mean values over all available estimates for each country. Mean elasticities for the UK and the US hide a very broad dispersion across studies. Difference in elasticity size may be driven by heterogeneity in work preferences across countries and over time, or by methodological reasons. As far as genuine international differences are concerned, we suggest that larger wage-elasticities prevail in countries where women's participation is low: This seems to be the case in our survey estimates for Ireland and Italy, which is confirmed in the discussions in Callan et al. (2009) and Aaberge et al. (2002) for these two countries respectively. In contrast, women's participation is high in Nordic countries and elasticities tend to be fairly small there, notably in Finland and Denmark but also Sweden and Norway. An exception is Blomquist and Hansson-Brusewitz (1990) for Sweden, but the authors examine data from the 1980s, while more recent evidence by Flood et al. (2004) confirm small hour elasticities for this country. Comparing Italy and Norway/Sweden, Aaberge et al. (1999) show that lower participation rates among married women in Italy leads to a larger potential for reforms that increase financial incentives to work. Larger elasticities coincide with more intermittent labor force participation patterns in Southern countries and Ireland, as opposed to more consistent participation and more constant hours in Scandinavian countries. Apart from these extreme cases, differences across EU countries, and notably countries of Continental Europe, may not be very large, as suggested by Evers et al. (2008). This is confirmed by Bargain et al. (2013): Using an harmonized framework for $17 \mathrm{EU}$ countries and the US, they find estimates for married women ranging in a narrow interval $.2-.6$. This is indeed where mean values lie in Figure 2 (top left quadrant), with few exceptions. Yet, direct comparisons 
across studies are necessarily muddled by methodological differences, notably the period of investigation and the estimation method. We investigate the role of these two factors in the next sub-section.

Single Mothers. This demographic group has received some attention in the literature because of its importance for welfare analysis, given its higher risk of poverty, and because single parent families were primarily concerned by reforms like tax credit extensions in the US (cf. Hotz and Scholz, 2003) or the UK (Blundell et al., 2000). This group is found to be more responsive to financial incentives than the average, at least in the UK, the US and Sweden. This is confirmed in Tables 2 and 3, where relatively large elasticities are shown in several studies, but not all. There is indeed much variance across estimates for lone mothers, in particular for the UK, as can be seen in Figure 2 (bottom right quadrant). Moderate estimates are found in some studies for the UK (Blundell et al., 1992) and the US (Dickert et al., 1995) while other papers point to much larger elasticities (e.g., Keane and Moffitt, 1998, for the US or many of the British studies). Importantly, this demographic group has become much larger in the recent period in Anglo-Saxon countries, which implies possible changes in the selection effect. That is, this group may be less negatively selected in terms of labor market participation in the recent period. For the US, Bishop et al. (2009) study all single women over a long period (1979-2003), using a simple estimation of hours and participation on repeated cross-sections. They report a significant decline in hour wage-elasticities over the period and relatively small elasticities in the recent years (at least compared to typical estimates for married women).

Men and Childless Singles Individuals. There is a long history of estimating male labor supply (see surveys of Hausman, 1985b, and Pencavel, 1986, for married men). Estimates of wage-elasticities for this group are usually very small, often not significant and sometimes negative. Studies reported in Table 1 broadly confirm these stylized facts for married men. There are few exceptions, with larger elasticities in Ireland and in some of the German studies. Evidence for childless single men and women, gathered in Table 2, is relatively limited, despite the growing proportion of this demographic group in the population. This limited evidence is essentially explained by methodological reasons. First, estimates are usually more precise for couples or single mothers than for childless single individuals. This can be due to the fact that there is less variation in labor market behavior among childless singles or that non-participation corresponds more often to demand-side constraints (rather than to voluntary choice) in their case. This argument equally applies to single men - yet the fit of labor supply model for married men should be overall better when male and female decisions are jointly estimated. Second, estimates stemming from natural experiments are also limited for this group, given the fact that most welfare reforms in Anglo-Saxon countries concerned individuals or households with children (see the discussion in Bargain and Doorley, 
2011). The few available estimates point to very small elasticities. ${ }^{5}$ For both men (married or single) and childless single women, estimates are not only small but very similar between studies for each country. This small variance across studies is illustrated in Figure 2 (top right quadrant for men and bottom left quadrant for childless single women). Nonetheless, these mean values may hide much variation in participation responses across different wage or income groups, with important implications for welfare analysis as suggested by see Eissa and Liebman (1996) and confirmed for single individuals in Bargain et al. (2013).

Income Elasticities. Most studies show negative income elasticities of labor supply, i.e. leisure (or non-market time) is a normal good. Yet, positive income elasticities are encountered in some studies, which include Kuismanen (1997) for Finland, Flood and MaCurdy (1992) for Sweden, van Soest (1995) for the Netherlands and Blau and Kahn (2007) and Cogan (1981) for the US. Also, despite being generally small, income elasticities vary across countries. Blundell and MaCurdy (1999) report that variation between studies regarding income elasticity appears to be greater than the corresponding variation with respect to wage elasticities. This is not confirmed in the series of estimates produced for 18 countries in Bargain et al. (2013) and neither in Tables 1-3 here. Note that very few estimates of income effects are available for single individuals.

\subsection{Year of Observation and Estimation Methods}

In Tables 1-3 and Figures 1-2, we have observed much variation across studies in the size of wage-elasticities, especially for married women and single mothers. This may correspond to genuine country differences in work preferences (individual preferences or social preferences embodied in the type of public childcare available in each country). Yet, using a uniform approach that rules out methodological differences, Bargain et al. (2013) show that the variation across countries is small. Therefore, most of the heterogeneity across studies must be driven by various methodological choices and in particular the period of observation and the estimation method. We focus on these two aspects hereafter, concentrating on married women and single mothers.

Time Trends. In Figure 3 (left quadrant), we plot estimates by year of data collection as specified in surveyed studies (Tables 1-3). A very clear declining trend emerges, showing in particular a concentration of low elasticities since the end of the 1990s, high elasticities in the 1970s and more variation in between. This pattern can be observed for both married women and single mothers. Given the small number of US studies reporting estimates for the latter group, we focus on married women in the right quadrant of Figure 3 where we distinguish

\footnotetext{
${ }^{5}$ For instance, Euwals and Van Soest (1999) report wage elasticities for childless single individuals in the Netherlands of around .10 - .11. For Germany, a series of studies report estimates between .10 and .36 for childless single men and women.
} 
between EU and US estimates. The trend is similar in both regions, with a strong negative correlation between the period of observation and the elasticity level. ${ }^{6}$ These findings tend to corroborate the result of Heim (2007) and Blau and Kahn (2007), who show that the labor supply elasticity of married women has strongly declined over time in the US, revealing a change in work preferences of women. Our results also suggest that a similar trend exist for EU countries. Yet, results in Heim (2007) and Blau and Kahn (2007) rely on a uniform approach for the different periods while our meta-analysis possibly mixes time effects and changes in modeling and estimation methods over time.

Estimation Methods. To investigate this point further, let us get back to survey Tables 13. A first observation is that early evidence using the Hausman technique points to relatively large own-wage elasticities for married women, sometimes close to 1, or even larger, for instance in early studies for France, Germany, Italy or the UK. In contrast, recent evidence based on discrete-choice models shows more modest elasticities for this demographic group, in a range between .1 and .5, with some exceptions. In Table 3, we observe a similar pattern for the US, with very large estimates in early studies, including Hausman (1981), and more modest and comparable elasticities in the recent studies (total hour wage-elasticities ranging between .2 and .4). Hence, we can conjecture that the estimation method explains time differences. With the Hausman approach, the combination of restrictive functional forms (linear labor supply) and estimation methods that impose theoretical consistency of the labor supply model everywhere in the sample (global satisfaction of Slutsky conditions) can lead to biased estimates and possibly an overstatement of work incentives, as discussed above. In addition, this approach is more sensitive to the model specification which may explain the large variance in estimates from the 1970s and 1980s. Mroz (1987) shows how the wage effects of married women's labor supply varies dramatically depending on whether and how one controls for non-random selection into work as well as to alternative exclusion restrictions in the instrument set for wages. Bourguignon and Magnac (1990) discuss the sensitivity of their results to the model specification and show that the Hausman approach can lead to implausibly high elasticity values, as they find in some of their specifications. Drawn from our tables, we can see for instance that married women's wage elasticity obtained with the Hausman approach vary from .28 (Triest, 1990) to .97 (Hausman, 1981) in the US, even when similar periods are considered (1983 and 1975 in these two studies respectively). For France, estimates for married women are also very high with the basic Hausman model, but almost zero when introducing fixed costs (cf. Bourguignon and Magnac, 1990). Estimates obtained with discrete choice models are somewhat more comparable from one study to the next. Yet there are still differences, which are more likely driven by selection criteria (for France, high elasticities are found for families with children in Choné et al., 2003) and alternative specifications of discrete-choice models (for instance, the degree of flexibility of

\footnotetext{
${ }^{6}$ We also find similar patterns when looking separately at hour wage-elasticities (correlation of -.59$)$ and participation wage-elasticities (correlation of -.54) for married women.
} 
the model, see Bargain, 2009).

Meta-Analysis. We attempt to clarify whether elasticities truly decline over time or whether this pattern is due to changes in estimation methods. To do so, we plot elasticities according to two broad modeling choices in Figure 4 (upper panels), namely estimates obtained with continuous models (which rely mainly on the Hausman approach for identification) and those from discrete-choice models (as recently used in many policy papers). Both graphs show that the former method was mainly used before 1990 while the latter took over in the 1990s and 2000s. For continuous models, there are nonetheless some observations in the more recent years so that we can suggest tentative interpretations. For our group of interest, and whether single mothers are included (right) or not (left), the time shrinking elasticity hypothesis is verified over all estimates relying on the Hausman approach. When differentiating between regions and focusing on married women (Figure 4, lower panels), this meta-analysis corroborates the find in Heim (2007) and Blau and Kahn (2007) for the US (both studies relying on a Hausman-type approach). A similar pattern is found for EU estimates but it is noticeable that there are very few estimates based on the Hausman model for the period after 1990 in EU countries, so the result is more fragile than for the US. If we turn to estimates from discrete choice models, the pattern is not so clear and few points of observations are available before the 1990s. There is a negative linear correlation $(-.37)$ between years and estimates due to the high density of very low estimates in the years 2000s. Yet it becomes close to null if we focus on the years before 1998. Thus, if the shrinking elasticity trend is driven by a change in preferences precisely between the 1970s/1980s and the 1990s/2000s, it cannot be captured by the available estimates based discrete choice modeling. This calls for further research comparing methods over the long run or replicating Heim (2007) and Blau and Kahn (2007) using the discrete-choice approach. We finally suggest a meta-analysis on the years for which we can find some common support in the use of the two empirical methods. That is, we restrict our sample to a period starting with the data year of the first estimate obtained with a discrete choice model (estimates on CPS 1985 in Eissa and Hoynes, 2004, and on the Dutch Labor Mobility Survey 1985 in van Soest et al., 1990). We regress elasticity values for married women on a set of simple model characteristics. Results are reported in Table 4. The main conclusion is that estimation periods ("year") turn out to play a significant role. An additional year decreases wage elasticities of married women by around .013, which amounts to a decrease of .31 over a period of 24 years (the duration considered in Heim, 2007). In contrast, the estimation method ("discrete model" dummy) is broadly insignificant. That is, the "overestimation" due to the Hausman model is not particularly visible when time effects are taken into account. Results are basically unchanged whether we consider total hour elasticities or participation response alone. The same is true if we focus on EU estimates only or if we extend the period to all the years in our 
sample of estimates for married women (last column of Table 4). ${ }^{7}$ Thus it seems that this meta-regression confirms the graphical analysis above, both for the US and EU countries. The limitation due to the limited common support nonetheless applies here too. Additional results in Table 4 show that modeling options affect elasticity size very marginally. An exception is the use of desired rather than observed hours, which inflates hour wage-elasticities. This necessarily reflects the role of demand-side or institutional constraints on working time and the fact that models estimated on observed work duration do underestimate potential labor supply responses.

\section{Conclusion}

In this paper, we provide an extensive survey of studies estimating static labor supply elasticities for Western Europe and the US. We do not only confirm most of the usual stylized facts from older reviews but also derive original results concerning the variation in labor supply responses across studies. While Bargain et al. (2013) show that international heterogeneity in work preference matters but is small, we investigate the role of two factors that greatly influence the variance in elasticity size across studies, namely the time period and the estimation method. Large elasticities are mainly due to labor market conditions of the 1970s and 1980s (notably more intermittent female labor market participation than in the recent period) and to the use of Hausman-type of model estimation. More recent estimates based on structural discrete-choice models with tax-benefit simulations show smaller estimates and relatively more similarity across studies. More estimates than what is currently available are required to disentangle the relative contribution of the time effect on the one hand (i.e. larger elasticities in the 1970s/1980s driven by lower female participation) and estimation methods on the other (i.e. overestimation due to the Hausman model). Our meta-analysis nonetheless confirms that elasticities for married women have declined over time in the US (as shown in Heim, 2007, and Blau and Kahn, 2007) and extends this result to the EU. This time effect reflects a change in work preferences - and possibly social preferences embodied in public childcare institutions - and a stronger attachment of women to the labor market. It is consistent with similar explanations for cross-country differences (Bargain et al., 2013), i.e. the fact that countries with more firmly established female participation show smaller elasticities.

\section{References}

[1] Aaberge, R., U. Colombino and S. Strøm (1999): "Labour Supply in Italy: An Empirical Analysis of Joint Household Decisions, with Taxes and Quantity Constraints",

\footnotetext{
${ }^{7}$ We do not report similar estimations for the US only given the small number of observations in this case.
} 
Journal of Applied Econometrics,14, 403-422.

[2] Aaberge R., Colombino U. and T. Wennemo (2002): "Heterogeneity in the elasticity of labour supply in Italy and some policy implications", WP CHILD \#21/2002.

[3] Aaberge, R., U. Colombino, and S. Strøm (2004): "Do More Equal Slices Shrink the Cake? An Empirical Investigation of Tax-Transfer Reform Proposals in Italy," Journal of Population Economics, 17, 767-785.

[4] Aaberge R. and U. Colombino (2012): "Accounting for family background when designing optimal income taxes: a microeconometric simulation analysis", Journal of Population Economics, 25(2), 41-761

[5] Alesina A., Glaeser E. and Sacerdote B. (2005): "Work and Leisure in the US and Europe: Why so different", NBER Macroeconomic Annual

[6] Andrén, T. (2003): "A Structural Model of Childcare, Welfare, and the Labor Supply of Single Mothers", Labour Economics, 10(2), 133-147.

[7] Arellano, M., and C. Meghir (1992): "Female Labour Supply and on the Job search: An Empirical Model Estimated Using Complementary Data Sets", Review of Economic Studies, 59, 537-559.

[8] Arrufat, J. L. and Zabalza, A. (1986): "Female Labour Supply with Taxation, Random Preferences and Optimization Errors", Econometrica, 54 (1), 47 - 63

[9] Bargain, O. (2009): "Flexible labour supply models", Economics Letters, 105, 103-105

[10] Bargain, O. and K. Orsini (2006): "In-work policies in Europe: Killing two birds with one stone?", Labour Economics 13, 667-697

[11] Bargain, O., Caliendo, M., Haan, P., Orsini, K. (2010) : "'Making Work Pay' in a Rationed Labour Market", Journal of Population Economics, 23(1), 323-351

[12] Bargain, O. and K. Doorley (2011): "Caught in the trap? Welfare's disincentive and the labor supply of single men", Journal of Public Economics, 95(9-10), 1096-1110

[13] Bargain, O., Orsini, K. and Peichl, A. (2013): "Comparing Labor Supply Elasticities in Europe and the US: New Results", IZA Discussion Paper.

[14] Bingley, P. and I. Walker (1997): "The Labour Supply, Unemployment and Participation of Lone Mothers in In-Work Transfer Programmes", Economic Journal, 107, 1375-1390

[15] Bishop, K., B. Heim, K. Mihaly (2009): "Single Women's Labor Supply Elasticities: Trends and Policy Implications," Industrial and Labor Relations Review, 63(1), 146-168

[16] Blanchard, O. (2006), discussion of "Do taxes explain European employment? Indivisible labor, human capital, lotteries and savings" (by L. Ljungqvist and T. Sargent), NBER Macroeconomics Conference, 2006 
[17] Blau, F. and L. Kahn (2007): "Changes in the Labor Supply Behavior of Married Women: 1980-2000". Journal of Labor Economics, 25, pp. 393-438.

[18] Bloemen, H. G. (2009): "An empirical model of collective household labour supply with non-participation", Economic Journal, 120, 183-214

[19] Bloemen, H. G. (2010): "Income taxation in an empirical collective household labour supply model with discrete hours", IZA Discussion Papers, No. 4697.

[20] Blomquist, S. (1983): "The Effect of Income Taxation on the Labor Supply of Married Men in Sweden", Journal of Public Economics, 22, 169-197.

[21] Blomquist, S., and U. Hansson-Brusewitz (1990): "The Effect of Taxes on Male and Female Labor Supply in Sweden", Journal of Human Resources, 25, 317-357.

[22] Blomquist, S. and W. Newey (2002): "Nonparametric estimation with nonlinear budget sets", Econometrica, 70, 6, 2455-2480.

[23] Blundell, R.W. and I. Walker (1986), "A life cycle consistent empirical model of labour supply using cross section data", Review of Economic Studies, 53: 539-558.

[24] Blundell, R.W., A. Duncan and C. Meghir (1992), "Taxation and empirical labour supply models: lone parents in the UK", Economic Journal, 102: 265-278.

[25] Blundell, R.W., A. Duncan, and C. Meghir (1998): "Estimating Labor Supply Responses Using Tax Reforms", Econometrica, 66, 827-861.

[26] Blundell, R.W., J. Ham and C. Meghir (1987), "Unemployment and female labour supply", Economic Journal, 97: 44-64.

[27] Blundell, R.W. and T. MaCurdy (1999): "Labor Supply: A Review of Alternative Approaches", in Ashenfelter and Card (eds), Handbook of Labor Economics, vol.3A, ch.27, Elsevier North-Holland.

[28] Blundell, R.W., A. Duncan, J. McCrae and C. Meghir (2000): "The Labour Market Impact of the Working Families' Tax Credit", Fiscal Studies, 21, 1, 75-103.

[29] Blundell, R.W., T. MaCurdy and C. Meghir (2007): "Labor Supply Models: Unobserved Heterogeneity, Nonparticipation and Dynamics", Handbook of Econometrics, Volume 6A Chapter 69 Heckman and Leamer eds

[30] Bonin, H., W. Kempe and H. Schneider (2002): "Household Labor Supply Effects of Low-Wage Subsidies in Germany", Journal of Applied Social Science Studies.

[31] Bourguignon, F. and T. Magnac (1990): "Labour supply and taxation in France", Journal of Human Resources, 25, 358-389.

[32] Brewer, M., A. Duncan, A. Shephard, M.J. Suarez (2006): "Did the Working Families' Tax Credit work? The impact of in-work support on labour supply in Great Britain", Labour Economics,13(6), 699-720. 
[33] Brink, A., K. Nordblom and R. Wahlberg (2007) "Maximum Fee versus Child Benefit: A Welfare Analysis of Swedish Child-Care Fee Reform", International Tax and Public Finance, Vol.14 (4), 457-480.

[34] Callan, T and A. van Soest (1996): "Family Labour Supply and Taxes in Ireland", ESRI working paper.

[35] Callan, T., A. van Soest and J. Walsh (2009): "Tax Structure and Female Labour Supply: Evidence from Ireland", Labour, 23(1), 1-35

[36] Carbonnier, C. (2008): "Spouse labor supply: fiscal incentive and income effect, evidence from French fully joint income tax system", working paper THEMA

[37] Chetty, R., A. Guren, D. Manoli, and A. Weber (2011): "Are micro and macro labor supply elasticities consistent? A review of evidence on the intensive and extensive margins", American Economic Review 101 (May), 471-75.

[38] Choné, P., D. Le Blanc and I. Robert-Bobée (2003): "Female labor supply and child care in France", CREST working paper.

[39] Clauss, M. and R. Schnabel (2006): "Distributional and Behavioural Effects of the German Labour Market Reform", ZEW working paper.

[40] Cogan, J. (1981): "Fixed Cost and Labour Supply", Econometrica, 49, 945-964

[41] Colombino, U., and D. del Boca (1990): "The Effect of Taxes on Labor Supply in Italy", Journal of Human Resources, 25, 390-414.

[42] Crespo, L. (2006): "Estimation and Testing of Household Labour Supply Models: Evidence from Spain", mimeo

[43] Dagsvik, J. K., Jia, Z., Orsini, K. and van Camp, G. (2011): "Subsidies on low-skilled workers' social security contributions: the case of Belgium", Empirical Economics, 40(3): 779-806.

[44] Dagsvik, J. K. and Strøm, S. (2006): "Sectoral labor supply, choice restrictions and functional form", Journal of Applied Econometrics, 21: 803-826.

[45] Dearing, H., H. Hofer, C. Lietz, R. Winter-Ebmer, K. Wrohlich (2007): "Why Are Mothers Working Longer Hours in Austria than in Germany? A Comparative Microsimulation Analysis", Fiscal Studies, 28 (4), 463-495

[46] Devereux, P. (2003): "Changes in Male Labor Supply and Wages", Industrial and Labor Relations Review, 56, 409-428.

[47] Devereux, P. (2004): "Changes in Relative Wages and Family Labor Supply", Journal of Human Resources, 39, 696-722.

[48] Dickert, S., S. Houser and J.K. Scholz (1995): "The Earned Income Tax Credit and Transfer Programs: A Study of Labor Market and Program Participation." in J. Poterba (ed.), Tax Policy and the Economy 9th ed., 1-50. 
[49] Donni, O. and N. Moreau (2007): "Collective Labor Supply: A Single-Equation Model and Some Evidence from French Data.", Journal of Human Resource, 42(1), 214246.

[50] Eissa, N. and H. Hoynes (2004): "Taxes and the Labor Market Participation of Married Couples: The Earned Income Tax Credit", Journal of Public Economics, 88, 9-10, 1931-1958.

[51] Eissa, N. and Liebman, J. (1996): "Labor supply response to the earned income tax credit", Quarterly Journal of Economics 111(2): 605-637.

[52] Ermisch, J \& Wright, R. (1991), "Welfare Benefits and Lone Parents' Employment in Great Britain", The Journal of Human Resources, 26 (3), 424 - 45

[53] Euwals, R. and A. Van Soest (1999): "Desired and actual labor supply of unmarried men and women in the Netherlands", Labor Economics, 6, 95-118.

[54] Evers, M., R. de Mooij, D. van Vuuren (2008): "The wage elasticity of labour supply: a synthesis of empirical estimates", De Economist, 156:25-43

[55] Fernández-Val, I. (2003): "Household Labor Supply: Evidence for Spain", Investigaciones Económicas, 27(2), 239-275.

[56] Flood, L. and MaCurdy, T (1992), "Work disincentive effects of taxes: an empirical study of Swedish men", Carnegie-Rochester Conference Series on Public Policy

[57] Flood, L., J. Hansen and R. Wahlberg (2004): "Household Labour Supply and Welfare Participation in Sweden", Journal of Human Ressources, 39 (4), 1008-1032.

[58] Flood, L. and Islam, N. (2005): "A monte carlo evaluation of discrete choice labour supply models", Applied Economics Letters, 12(5): 263-266.

[59] Frederiksen, A., E. Graversen and N. Smith (2008): "Overtime work, dual job hlding and taxation", Research in Labor Economics, 28, 25-55

[60] Fuchs, V.R., A. B. Krueger and J. M. Poterba (1998): "Economists' Views about Parameters, Values, and Policies: Survey Results in Labor and Public Economics", Journal of Economic Literature, 36(3), 1387-1425

[61] Fuest, C., A. Peichl and T. Schaefer (2008): "Is a flat rate reform feasible in a grownup democracy of Western Europe? A simulation study for Germany" International Tax and Public Finance 15 (5): 620-636.

[62] García, I. and M.J. Suárez (2003): "Female labour supply and income taxation in Spain: The importance of behavioural assumptions and unobserved heterogeneity specification", Hacienda Pública Española / Revista de Economía Pública, 164(1): $9-27$

[63] González, L. (2008): "Single mothers, welfare, and incentives to work", LABOUR 22 (3) $447-468$ 
[64] Haan, P. and Steiner V. (2004): "Distributional and fiscal effects of the German tax reform 2000 - a behavioral microsimulation analysis", DIW discussion paper, 419, Berlin.

[65] Haan, P. and Uhlendorff, A. (2007): "Intertemporal Labor Supply and Involuntary Unemployment", IZA Discussion Paper No. 2888.

[66] Hall, R.E. (1973): "Wages, Income and Hours of Work in the U.S. Labor Force" in Income Maintenance and Labor Supply, ed. Cain and Watts, Chicago, Markham.

[67] Hausman, J.A. (1981): "Labor Supply", in How Taxes Affect Economic Behavior, ed.H. Aaron and J.Pechman, The Brookings Institution, Washington D.C., 27-72.

[68] Hausman J.A. (1985a): "The Econometrics of Nonlinear Budget Sets", Econometrica, $53,1255-82$.

[69] Hausman J.A. (1985b): "Taxes and Labor Supply" in Handbook of Public Economics, ed. Auerbach and Feldstein, Amsterdam, North-Holland.

[70] Hausman, J.A. and P. Ruud (1984): "Family labor supply with taxes", American Economic Review, 74, 242-248.

[71] Heim, B.T. (2007): "The Incredible Shrinking Elasticities: Married Female Labor Supply, 1978-2002." Journal of Human Resources 42(4): 881-918.

[72] Heim, B.T. (2009): "Structural Estimation of Family Labor Supply with Taxes: Estimating a Continuous Hours Model Using a Direct Utility Specification." Journal of Human Resources 44(2): 350-385.

[73] Heim, B.T. and B.D. Meyer (2002): "Structural Labor Supply Models when Budget Constraints are Nonlinear", Northwestern University Working Paper.

[74] Heim, B.T. and B.D. Meyer (2003): "Work costs and nonconvex preferences in the estimation of labor supply models", Journal of Public Economics, 88(11)2323-38

[75] Hotz, J. and K. Scholz (2003): "The Earned Income Tax Credit", in Means-Tested Transfer Programs in the United States, R. Moffitt (ed.), The University of Chicago Press and NBER, 141-197

[76] Hoynes, H. (1996): "Welfare Transfers in Two-Parent Families: Labor Supply and Welfare Participation Under AFDC-UP", Econometrica, 64, 295-332.

[77] Jenkins, S. (1992), "Lone Mothers' Employment and Full Time Work Probabilities", Economic Journal, 102 (411), 310 - 320.

[78] Kaiser, H., P. Spahn and U. van Essen (1992), "Income taxation and the supply of labour in West Germany", Jahrbücher für Nationalökonomie und Statistik, 209/1-2: 87-105.

[79] Keane, M. and R. Moffit (1998): "A Structural Model of Multiple Welfare Program Participation and Labor Supply", International Economic Review, 39, 553-589. 
[80] Keane, M.P. (2011): "Labor Supply and Taxes: A Survey", Journal of Economic Literature, 49:4, 961-1075

[81] Keane, M.P. and R. Rogerson (2012): "Micro and Macro Labor Supply Elasticities: A Reassessment of Conventional Wisdom." Journal of Economic Literature, 50(2): $464-76$.

[82] Killingsworth, M. and J. Heckman (1986): "Female labor supply: a survey", in O. Ashenfelter and R. Layard (eds), Handbook of Labor Economics, vol.1, Amsterdam, North-Holland.

[83] Kuismanen, M. (1997): "Labour Supply, Unemployment and Income Taxation: An Empirical Application,' Working Paper, Government Institute for Economic Research, Helsinki, University College London.

[84] Labeaga, J.M., X. Oliver and A. Spadaro (2005): "Discrete choice models of labour supply, behavioural microsimulation and the Spanish tax reform", Journal of Economic Inequality, 6(3), 247-273,

[85] Laroque, G. and B. Salanié (2002): "Labor market, institutions and employment in France", Journal of Applied Econometrics, 17, 25-48.

[86] Lemieux, T. and K. Milligan (2008): "Incentive effects of social assistance: A regression discontinuity approach," Journal of Econometrics, vol. 142(2), 807-828.

[87] MaCurdy, T. (1992): "Work Disincentive Effects of Taxes: A Reexamination of some evidence", American Economic Review, Papers and Proceedings, 82, 243-249.

[88] MaCurdy, T., P. Green, and H. Paarsch (1990): "Assessing Empirical Approaches for Analyzing Taxes and Labor Supply", Journal of Human Resources, 25, 415-490.

[89] Mastrogiacomo, M., Bosch, N. M., Gielen, M. D.A.C. and Jongen, E. L. W. (2013): "A structural analysis of labour supply elasticitiesin the Netherlands", CPB Discussion Paper 235.

[90] McClelland, R. and S. Mok (2012): "A Review of Recent Research on Labor Supply Elasticities", Washington, DC: Congressional Budget Office.

[91] Meghir, C. and D. Phillips (2008): "Labour Supply and Taxes", The Mirrlees Review: Reforming the Tax System for the 21st Century.

[92] Mroz, T. (1987): “The Sensitivity of an Empirical Model of Married Women's Hours of Work to Economic and Statistical Assumptions." Econometrica 55(4): 765-799.

[93] Orsini, K. (2012): "Tax benefit reforms and the labor market: Evidence from Belgium and other EU countries", Labour Economics, 19 (1), 129-138, and previously Leuven University, working paper, 2006.

[94] Orsini, K. (2007): "Ex-ante Evaluations of Tax and Benefit Reforms in the EU: What Can We Learn?", Leuven University, working paper 
[95] Pencavel, J. (1986): "Labor supply of men: a survey", in O. Ashenfelter and R. Layard (eds), Handbook of Labor Economics, vol.1, Amsterdam, North-Holland.

[96] Pencavel, J. (1998): "The Market Work Behavior and Wages of Women, 1975-94", Journal of Human Resources, 33 (4), 771-804.

[97] Pencavel, J. (2002): "A Cohort Analysis of the Association between Work Hours and Wages among Men", Journal of Human Resources, 37(2), 251- 274

[98] Piketty, T. (1998): "L'impact des incitations financières au travail sur les comportements individuels: une estimation pour le cas français.", Economie et Prévision 132-133, 1-35.

[99] Prescott, E.C. (2004): "Why do Americans work so much more than Europeans?," Quarterly Review, Federal Reserve Bank of Minneapolis, issue Jul, 2-13.

[100] Saez, E., J. Slemrod, and S.H. Giertz (2012): "The Elasticity of Taxable Income with Respect to Marginal Tax Rates: A Critical Review." Journal of Economic Literature, 50(1): 3-50

[101] Smith, N. (1995): "A panel study of labour supply and taxes in Denmark", Applied Economics, 27 (5),419-429.

[102] Stancanelli, E. (2008): "Evaluating the impact of the French tax credit on the employment rate of women", Journal of Public Economics, 92, 10-11, 2036-47.

[103] Steiner, V. and K. Wrohlich (2004): "Household Taxation, Income Splitting and Labor Supply Incentives - A Microsimulation Study for Germany", CESifo Economic Studies, 50, 3, 541-568.

[104] Triest, R.K. (1990): "The effect of income taxation on labor supply in the United States", Journal of Human Resources, 25, 491- 516.

[105] van Soest, A. (1995): "Structural Models of Family Labor Supply: a Discrete Choice Approach", Journal of Human Resources, 30, 63-88.

[106] van Soest, A. and M. Das (2001): "Family labor supply and proposed tax reforms in the Netherlands", De Economist, 149(2), 191-218.

[107] van Soest, A., M. Das and X. Gong (2002): "A structural labor supply model with non-parametric preferences", Journal of Econometrics (Annals), 107, 345-374.

[108] van Soest, A., I. Woittiez and A. Kapteyn (1990): "Labour supply, income taxes and hours restrictions in the Netherlands", Journal of Human Resources, 25, 517-558.

[109] Vlasblom, J. D., P. P. De Gijsel and J. J. Siegers (2001): "Taxes, Female Labour Supply and Household Income: Differences between the Netherlands and the Federal Republic of Germany", Applied Economics, 33, 735-744

[110] Walker, I. (1990), "The Effect of Income Support Measures on the Labour Market Behaviour of Lone Mothers", Fiscal Studies, 11 (2), pp. 55 - 74 
[111] Wrohlich, K. (2006): "Child Care Costs and Mothers' Labor Supply: An Empirical Analysis for Germany", DIW Berlin

[112] Ziliak, J.P. and T.J. Kniesner (1999): "Estimating Life Cycle Labor Supply Tax Effects", Journal of Political Economy, 107 (2), 326-59. 

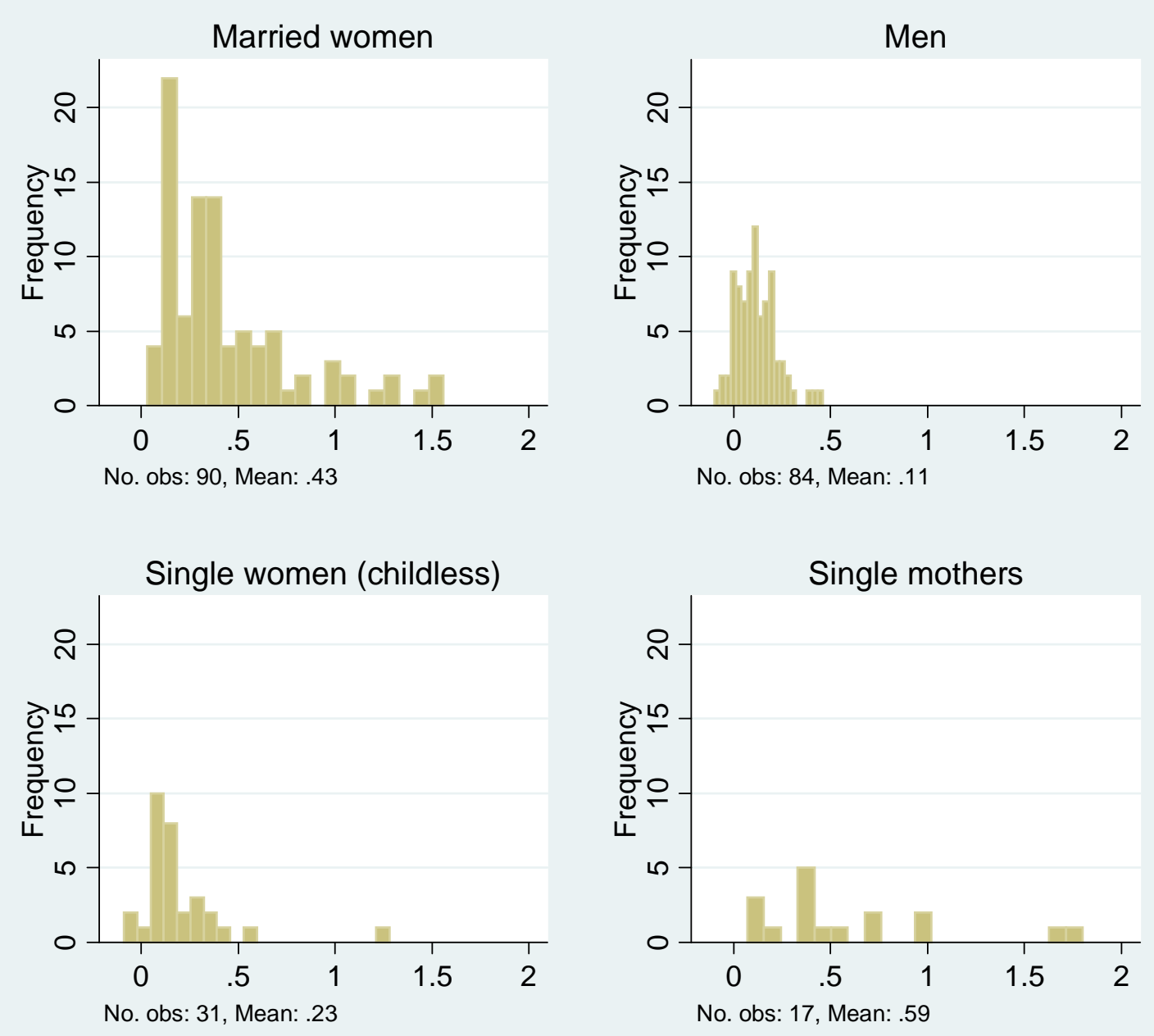

Figure 1: Distribution of Wage-Elasticities by Demographic Group 

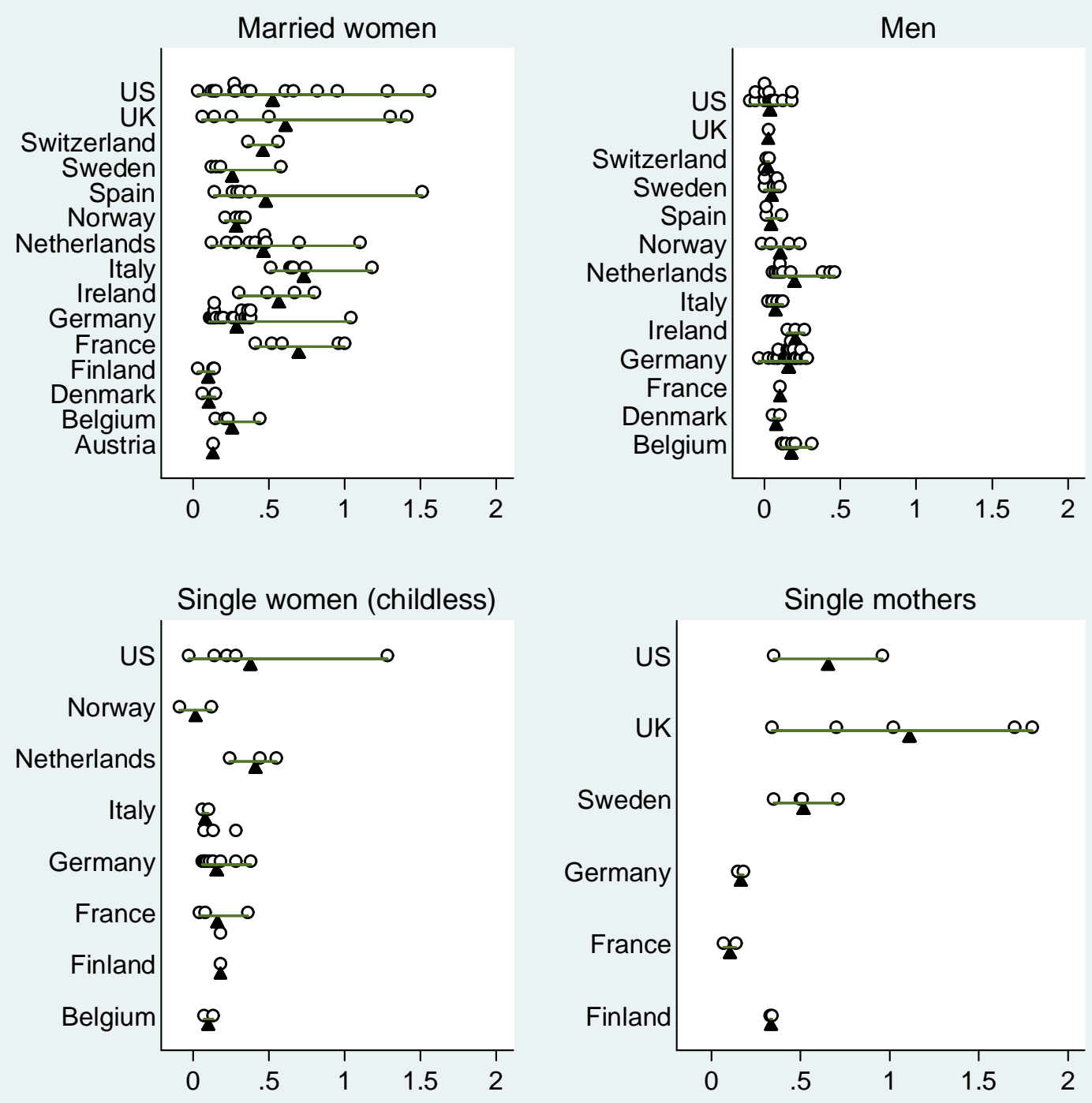

Figure 2: Distribution of Wage-Elasticities by Demographic Group and Country 

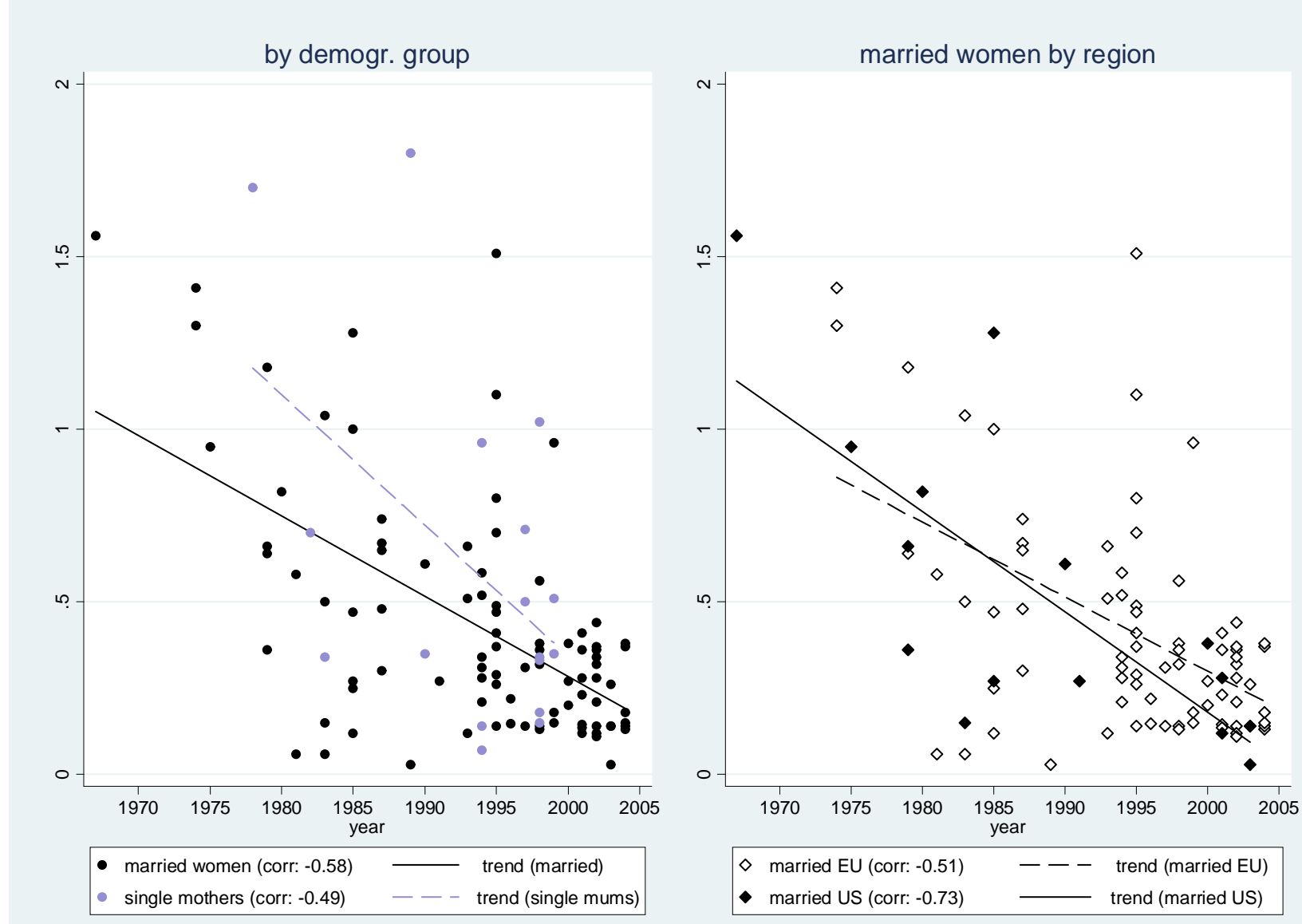

Figure 3: Time Trend in Wage-Elasticities of Married Women and Single Mothers 

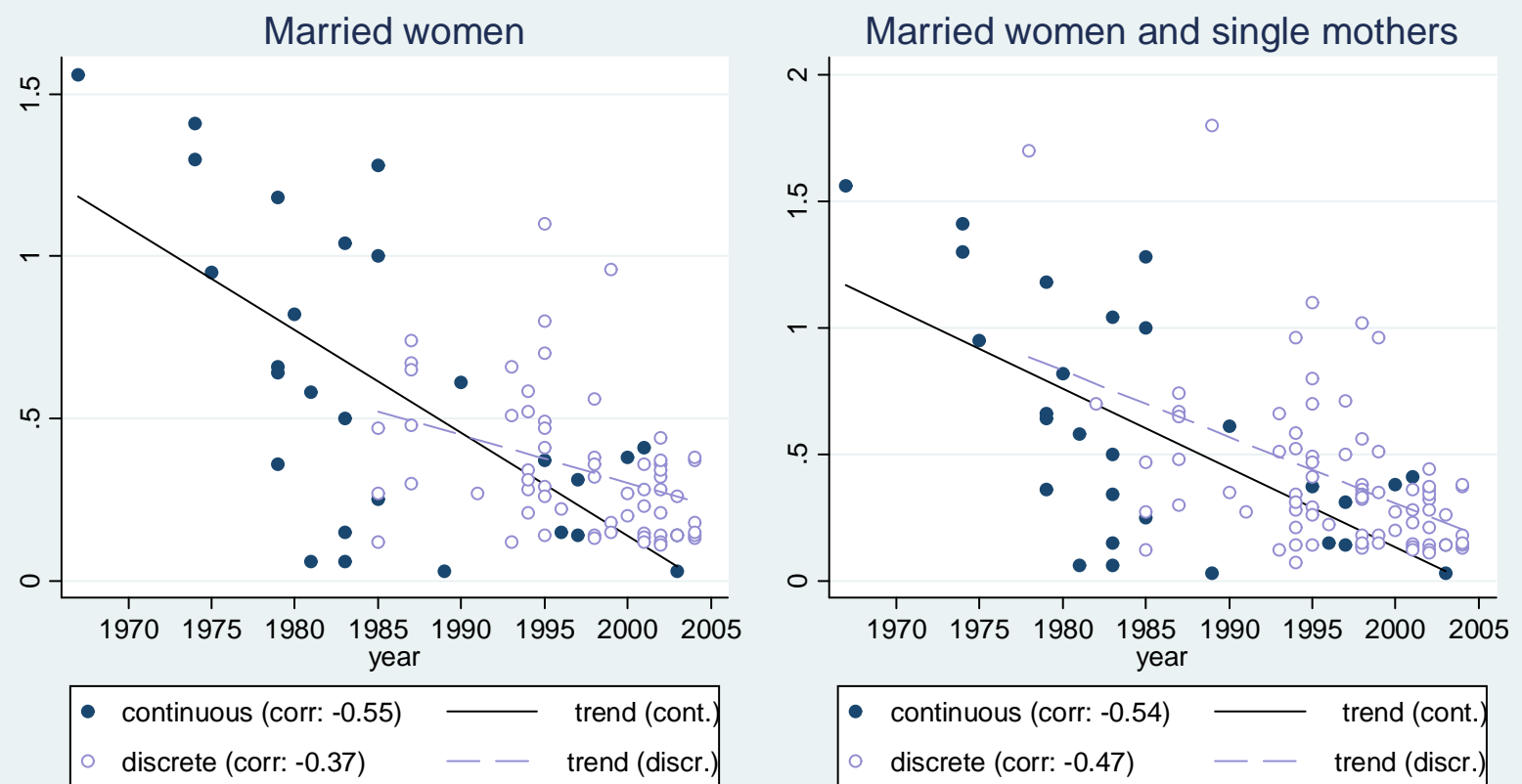

Married women, EU
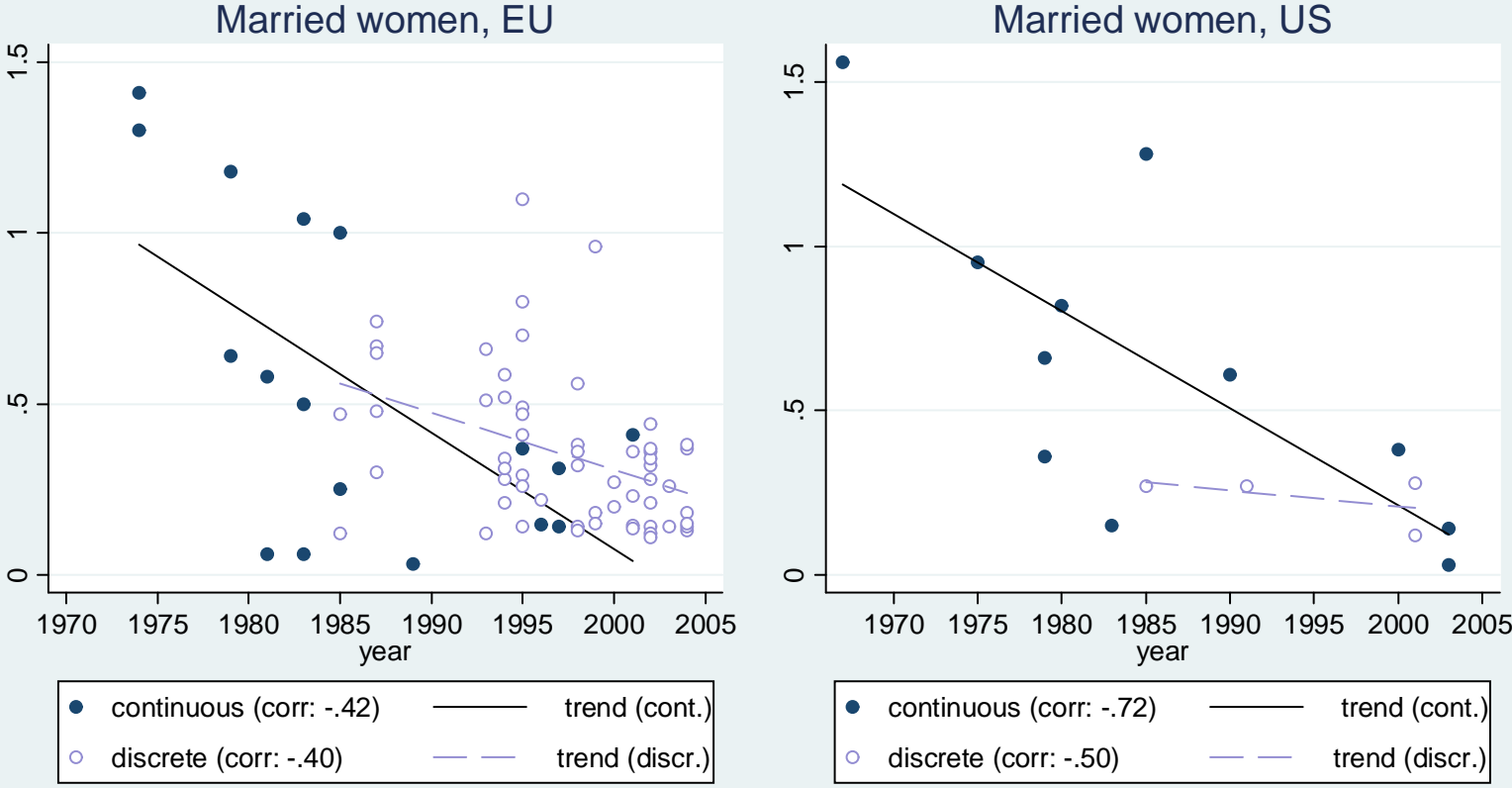

Figure 4: Time Trend in Wage-Elasticities: by Broad Estimation Methods 
Table 1: Labor Supply Elasticities in Europe: Couples

\begin{tabular}{|c|c|c|c|c|c|c|c|c|c|c|c|}
\hline \multirow{3}{*}{$\begin{array}{l}\text { Country } \\
\text { Austria }\end{array}$} & \multirow[b]{2}{*}{ Authors } & \multirow[b]{2}{*}{ Data selection } & \multirow[b]{2}{*}{ Model } & \multirow[b]{2}{*}{ Specification } & \multirow[b]{2}{*}{ Tax-benefit } & \multicolumn{2}{|c|}{$\begin{array}{l}\text { Female wage elast. } \\
\end{array}$} & \multicolumn{2}{|c|}{ Male wage elast. } & \multicolumn{2}{|c|}{ Income elast. } \\
\hline & & & & & & hours & particip. & hours & particip. & female & male \\
\hline & $\begin{array}{l}\begin{array}{l}\text { Dearing } \\
(2007)\end{array} \\
\text { et }\end{array}$ & $\begin{array}{l}\text { SILC (2004), at least } 1 \text { child } \\
\text { aged }<10\end{array}$ & $\mathrm{D}$ & QU; M & ITABENA & & {$[.07,19] @$} & & & & \\
\hline \multirow[t]{2}{*}{ Belgium } & Orsini $(2007,2012)$ & $\begin{array}{l}\text { Panel Survey of Belgian } \\
\text { Households }(2000-01) \text {, work- } \\
\text { ing age }\end{array}$ & D & $\begin{array}{l}\mathrm{QU} \text { and } \mathrm{GU}+ \\
\text { PTD; J }\end{array}$ & MODETE & {$[.16,31]$} & {$[.10, .19]$} & {$[.10, .18]$} & {$[.08,15]$} & & \\
\hline & $\begin{array}{l}\text { Dagsvik et al. } \\
(2011)\end{array}$ & $\begin{array}{l}\text { National Register Data } \\
\text { (2002), working age }\end{array}$ & D & polynomial & MIMOSI & .44 & .21 & .31 & .18 & & \\
\hline \multirow[t]{2}{*}{ Denmark } & Smith (1995) & $\begin{array}{l}\text { Administrative register data } \\
(1980-86)\end{array}$ & $\mathrm{C}$ & SL & PL & .061 & & .093 & & 0 & -.025 \\
\hline & $\begin{array}{l}\text { Frederiksen et al. } \\
(2008)\end{array}$ & $\begin{array}{l}\text { Survey by Statistics Denmark } \\
(1996) \text {, age } 18-59\end{array}$ & C & $\mathrm{SL}, \mathrm{FC}$ & PL & .148 & & .05 & & -.007 & -.006 \\
\hline \multirow[t]{2}{*}{ Finland } & Kuismainen (1997) & $\begin{array}{l}\text { LFS (1989), survey \& tax reg- } \\
\text { ister; } 25-60\end{array}$ & C & $\mathrm{SL}, \mathrm{R}$ & PL & {$[0,06]$} & & & & {$[.11,27]$} & \\
\hline & $\begin{array}{l}\text { Bargain \& Orsini } \\
(2006)\end{array}$ & $\begin{array}{l}\text { IDS (1998), working age, men } \\
\text { all employed }\end{array}$ & D & $\mathrm{QU}+\mathrm{FC} ; \mathrm{M}$ & EUROMOD & {$[.10,18]$} & {$[\cdot 10, .17]^{*}$} & & & & \\
\hline \multirow[t]{5}{*}{ France } & $\begin{array}{l}\text { Bourguignon } \& \\
\text { Magnac (1990) }\end{array}$ & $\begin{array}{l}\text { LFS (1985), couples aged 18- } \\
60\end{array}$ & $\mathrm{C} / \mathrm{T}$ & $\mathrm{LL}+\mathrm{R} ; \mathrm{M}$ or J & PL, D & $\begin{array}{l}1 \text { (.05 with } \\
\text { FC) }\end{array}$ & & .10 & & $\begin{array}{l}-.03 \quad(-.02 \\
\text { with FC) }\end{array}$ & -.07 \\
\hline & $\begin{array}{l}\text { Laroque \& Salanie } \\
(2002)\end{array}$ & $\begin{array}{l}\text { matched LFS-Tax returns } \\
\text { (1999), women aged 25-49 }\end{array}$ & D & $\begin{array}{l}\text { joint particip. \& } \\
\text { wage; unempl. \& } \\
\text { min. wage }\end{array}$ & own calc. & & $(.96)$ & & & $/-.11^{*}$ & \\
\hline & Choné et al. (2003) & $\begin{array}{l}\text { matched LFS-Tax returns } \\
\text { (1997), working age, children } \\
\text { aged }<6\end{array}$ & D & $\begin{array}{l}\text { QU, joint wage \& } \\
\mathrm{CC} \text {; min. wage }\end{array}$ & own calc. & 1.05 & {$[.8,9] @$} & & & $-.19 /-.18^{*}$ & \\
\hline & $\begin{array}{l}\text { Bargain \& Orsini } \\
(2006)\end{array}$ & $\begin{array}{l}\text { HBS }(1994 / 5) \text {, working age } \\
\text { women, men all employed }\end{array}$ & D & $\mathrm{QU}+\mathrm{FC} ; \mathrm{M}$ & EUROMOD & {$[.52,, 65]$} & {$[.46, .58]^{*}$} & & & & \\
\hline & $\begin{array}{l}\text { Donni \& Moreau } \\
(2007)\end{array}$ & $\begin{array}{l}\text { HBS (2001), aged } 20-60 \text {, } \\
\text { all employed, no children } \\
\text { aged }<3\end{array}$ & C & $\begin{array}{l}\text { QL; s-conditional } \\
\text { collective LS }\end{array}$ & no taxation & {$[.24,59]$} & & & & {$[-.35,-.06]$} & \\
\hline \multirow[t]{11}{*}{ Germany } & Kaiser et al. (1992) & SOEP (1983), working age & $\mathrm{C}$ & LL & $\mathrm{C}, \mathrm{NC}, \mathrm{D}$ & 1.04 & & -.04 & & -.18 & -.28 \\
\hline & Bonin et al. (2002) & $\begin{array}{l}\text { SOEP (2000), working age, } \\
\text { W \& E }\end{array}$ & D & $\mathrm{TL}+\mathrm{PTD} ; \mathrm{J}$ & IZAmod & .27 & .20 & .21 & .19 & $.15 / .09$ & $.01 / 0$ \\
\hline & $\begin{array}{l}\text { Steiner \& Wrohlich } \\
(2004)\end{array}$ & $\begin{array}{l}\text { SOEP (2002), working age, } \\
\text { W \& E }\end{array}$ & D & $\mathrm{TU}+\mathrm{PTD} ; \mathrm{J}$ & STSM & {$[.16, .55] @$} & {$[.07, .21] @$} & {$[.11,38] @$} & {$[.07,23] @$} & & \\
\hline & $\begin{array}{l}\text { Haan \& Steiner } \\
(2004)\end{array}$ & $\begin{array}{l}\text { SOEP (2002), working age, } \\
\text { W \& E, one- or two-earner } \\
\text { couples }\end{array}$ & D & $\mathrm{TU}+\mathrm{PTD} ; \mathrm{J}$ & STSM & {$[.08,56]$} & {$[.04,20]$} & {$[.08,46]$} & {$[.07,26]$} & & \\
\hline & $\begin{array}{l}\text { Bargain \& Orsini } \\
(2006)\end{array}$ & $\begin{array}{l}\text { SOEP (1998), working age, } \\
\text { men all employed, W \& E }\end{array}$ & D & $\mathrm{QU}+\mathrm{FC} ; \mathrm{M}$ & EUROMOD & {$[.31,45]$} & {$[.27, .38]^{*}$} & & & & \\
\hline & Haan (2006) & $\begin{array}{l}\text { SOEP (2001), W \& E; mar- } \\
\text { ried couples, 20-65 years }\end{array}$ & D & $\mathrm{TU}$ & STSM & {$[.34, .39]$} & {$[.13, .14]$} & {$[.19, .22]$} & {$[.12, .14]$} & & \\
\hline & $\begin{array}{l}\text { Clauss \& Schnabel } \\
(2006)\end{array}$ & $\begin{array}{l}\text { SOEP }(2004 / 5) \text {, couples aged } \\
20-65\end{array}$ & D & TU; J & STSM & .37 & .14 & .24 & .16 & & \\
\hline & Wrohlich (2006) & $\begin{array}{l}\text { SOEP (2002), working age, } \\
\text { W \& E }\end{array}$ & D & TU; J; CC & STSM & {$[.14, .53] @$} & {$[.06, .16] @$} & & & & \\
\hline & $\begin{array}{l}\text { Dearing et al. } \\
(2007)\end{array}$ & $\begin{array}{l}\text { SOEP }(2004) \text {, at least } 1 \text { child } \\
\text { aged }<10, \mathrm{~W}\end{array}$ & D & $\mathrm{QU} ; \mathrm{M}$ & STSM & & {$[.13,24] @$} & & & & \\
\hline & $\begin{array}{l}\text { Bargain et al. } \\
(2010)\end{array}$ & $\begin{array}{l}\text { SOEP (2003), working age, } \\
\text { potential one- or two-earner }\end{array}$ & $\mathrm{D} / \mathrm{H}$ & $\mathrm{QU}+\mathrm{PTD}, \mathrm{R} ; \mathrm{J}$ & STSM & {$[.19,34]$} & {$[.08,20]$} & {$[.05, .08]$} & {$[.04,13]$} & & \\
\hline & Fuest et al. (2008) & $\begin{array}{l}\text { SOEP (2004), working age, } \\
\text { W \& E, potential one- or two- } \\
\text { earner }\end{array}$ & D & $\mathrm{TU}+\mathrm{PTD} ; \mathrm{J}$ & FiFoSiM & .38 & .15 & .20 & .14 & & \\
\hline \multirow[t]{2}{*}{ Ireland } & $\begin{array}{l}\text { Callan \& van Soest } \\
(1996)\end{array}$ & IDS (1987), desired hours & $\mathrm{D} / \mathrm{H}$ & $\mathrm{TU}+\mathrm{FC}, \mathrm{R} ; \mathrm{J}$ & SWITCH & {$[.50,85]$} & $.31 / .20^{*}$ & {$[.10,20]$} & & & \\
\hline & Callan et al. (2009) & $\begin{array}{l}\text { Living in Ireland Survey } \\
\text { (1995), desired hours }\end{array}$ & D & $\mathrm{TU}+\mathrm{FC}, \mathrm{R} ; \mathrm{J}$ & SWITCH & {$[.71,90]$} & .49 & {$[.21,31]$} & $.20 / .21^{*}$ & & \\
\hline \multirow[t]{3}{*}{ Italy } & $\begin{array}{l}\text { Colombino \& Del } \\
\text { Boca }(1990)\end{array}$ & $\begin{array}{l}\text { Turin Survey of Couples } \\
\text { (1979), working age }\end{array}$ & C & LL & $\mathrm{PL}$ & 1.18 & .64 & & & .52 & \\
\hline & $\begin{array}{l}\text { Aaberge et al. } \\
(1999)\end{array}$ & $\begin{array}{l}\text { Survey of Income and Wealth } \\
\text { (1987), aged 20-70 }\end{array}$ & A & $\begin{array}{l}\text { non-linear hours, } \\
\text { exog. wage and } \\
\text { unearned inc. }\end{array}$ & own calc. & .74 & .65 & .053 & .046 & -.014 & -.003 \\
\hline & $\begin{array}{l}\text { Aaberge et al. } \\
(2002,04)\end{array}$ & $\begin{array}{l}\text { Survey of Income and Wealth } \\
\text { (1993) }\end{array}$ & A & GU; J & own calc. & .66 & .51 & .12 & .02 & & \\
\hline \multirow[t]{7}{*}{ Netherlands } & $\begin{array}{l}\text { van Soest et al. } \\
(1990)\end{array}$ & $\begin{array}{l}\text { Labor mobility survey (1985), } \\
\text { working age }\end{array}$ & $\mathrm{C} / \mathrm{D}$ & $\begin{array}{l}\text { LL, } \quad R ; \quad \text { discrete } \\
\text { wage-hours combi- } \\
\text { nations }\end{array}$ & PL & {$[.35,59]$} & .12 & {$[.15, .19]$} & & -.23 & -.01 \\
\hline & van Soest (1995) & SOEP (1987) & D & $\mathrm{TU}+\mathrm{PTD}, \mathrm{R} ; \mathrm{J}$ & own calc. & {$[.42, .54]$} & & {$[.05, .09]$} & & .008 & -.03 \\
\hline & $\begin{array}{l}\text { van Soest \& Das } \\
(2001)\end{array}$ & $\begin{array}{l}\text { SOEP (1995), aged 16-64, de- } \\
\text { sired hours }\end{array}$ & D & $\mathrm{TU}+\mathrm{FC}, \mathrm{R} ; \mathrm{J}$ & own calc. & {$[.67,74]$} & & {$[.07,10]$} & & & \\
\hline & $\begin{array}{l}\text { van Soest et al. } \\
(2002)\end{array}$ & $\begin{array}{l}\text { Dutch SOEP (1995), aged 16- } \\
64, \text { desired hours }\end{array}$ & D & $\begin{array}{l}\text { QU (+ more flex- } \\
\text { ible) + FC, R; si- } \\
\text { mult. wage estima- } \\
\text { tion, J }\end{array}$ & own calc. & {$[.83,1.36]$} & {$[.35, .58]^{*}$} & & & & \\
\hline & Bloemen (2009) & $\begin{array}{l}\text { SEP (1990-2001), couples } \\
\text { w/o children, age } 22-60\end{array}$ & D & $\mathrm{QL}$ & own & {$[.22, .61]$} & & {$[.24, .61]$} & & -.057 & \\
\hline & Bloemen (2010) & $\begin{array}{l}\text { SEP (1990-2002), couples } \\
\text { w/o children, age } 22-60\end{array}$ & D & $\mathrm{QU}, \mathrm{FC}$ & own & {$[.14, .31]$} & & {$[-.02, .03]$} & & & \\
\hline & $\begin{array}{l}\text { Mastrogiacomo et } \\
\text { al. (2013) }\end{array}$ & $\begin{array}{l}\text { Labour Market Panel (1999- } \\
\text { 2005) }\end{array}$ & D & $\mathrm{QU}, \mathrm{FC}$ & CPB model & {$[.22, .52]$} & {$[.17, .40]$} & {$[.05, .19]$} & {$[.05, .16]$} & & \\
\hline \multirow[t]{2}{*}{ Norway } & $\begin{array}{l}\text { Dagsvik, } \quad \text { Strom } \\
(2006)\end{array}$ & $\begin{array}{l}\text { Survey of Income and Wealth } \\
(1994 / 5) ; \text { married couples }\end{array}$ & D & polynomial & $\begin{array}{l}\text { Statistic } \\
\text { Norway } \\
\text { model }\end{array}$ & .65 & .28 & & & & \\
\hline & $\begin{array}{l}\text { Aaberge \& Colom- } \\
\text { bino (2012) }\end{array}$ & $\begin{array}{l}\text { Survey of Income and Wealth } \\
(1994 / 5) ; \text { married couples }\end{array}$ & D & polynomial & $\begin{array}{l}\text { Statistic } \\
\text { Norway } \\
\text { model }\end{array}$ & .21 & .31 & .23 & .16 & & \\
\hline
\end{tabular}


Table 1: Labor Supply Elasticties in Europe: Couples (cont.)

\begin{tabular}{|c|c|c|c|c|c|c|c|c|c|c|c|}
\hline \multirow{3}{*}{$\begin{array}{l}\text { Country } \\
\text { Spain }\end{array}$} & \multirow[b]{2}{*}{ Authors } & \multirow[b]{2}{*}{ Data selection } & \multirow[b]{2}{*}{ Model } & \multirow[b]{2}{*}{ Specification } & \multirow[b]{2}{*}{ Tax-benefit } & \multicolumn{2}{|c|}{ Female wage elast. } & \multicolumn{2}{|c|}{ Male wage elast. } & \multicolumn{2}{|c|}{ Income elast. } \\
\hline & & & & & & hours & particip. & hours & particip. & female & male \\
\hline & $\begin{array}{l}\text { García \& Suárez } \\
(2003)\end{array}$ & $\begin{array}{l}\text { ECHP (1994-95), aged 16-65, } \\
\text { obs. and desired hours }\end{array}$ & C & LL & taxes & .37 & $1.51^{*}$ & & & $\begin{array}{l}-.06 \\
\end{array}$ & \\
\hline & $\begin{array}{l}\text { Fernández-Val } \\
(2003)\end{array}$ & $\begin{array}{l}\text { ECHP (1994-99), aged <65 } \\
\text { and in work }\end{array}$ & C & $\begin{array}{l}\text { unitary/collective } \\
\text { model }\end{array}$ & no taxation & .31 & & & & & \\
\hline & Crespo (2006) & $\begin{array}{l}\text { ECHP (1994-99), aged<65 } \\
\text { and in work }\end{array}$ & $\mathrm{C}$ & $\begin{array}{l}\text { QL, } \\
\text { tary/collective }\end{array}$ & no taxation & .14 & & .01 & & & \\
\hline & $\begin{array}{l}\text { Labeaga, Oliver \& } \\
\text { Spadaro (2008) }\end{array}$ & ECHP (1995), working age & D & $\mathrm{QU}+\mathrm{FC} ; \mathrm{J}$ & $\begin{array}{l}\text { GLAD- HIS- } \\
\text { PANIA }\end{array}$ & .29 & .26 & .01 & .11 & & \\
\hline \multirow[t]{6}{*}{ Sweden } & Blomquist (1983) & $\begin{array}{l}\text { Level of Living Survey (1974), } \\
\text { all employed, aged } 25-55\end{array}$ & $\mathrm{C}$ & $\mathrm{LL}, \mathrm{R}$ & PL & & & .008 & & & -.03 \\
\hline & $\begin{array}{l}\text { Flood \& MaCurdy } \\
(1992)\end{array}$ & $\begin{array}{lr}\text { Household } & \text { Market- } \\
\text { Nonmarket Survey } & (1983), \\
\text { all employed, 25-65 } & \end{array}$ & C & $\mathrm{LL}$ and $\mathrm{SL}, \mathrm{R}$ & PL, D & & & {$[-.25, .21]$} & & & {$[-.01, .04]$} \\
\hline & $\begin{array}{l}\text { Blomquist \& } \\
\text { Hansson-Brusewitz } \\
(1990)\end{array}$ & $\begin{array}{l}\text { Level of Living Survey (1981), } \\
\text { all employed, aged 25-55 }\end{array}$ & $\mathrm{C}$ & LL and QL, R & $\begin{array}{l}\text { PL, } \mathrm{C} \text { and } \\
\mathrm{NC}\end{array}$ & {$[.38,77]$} & & {$[.08, .13]$} & & {$[-.24,-.03]$} & \\
\hline & $\begin{array}{l}\text { Blomquist } \\
\text { Newey (2002) }\end{array}$ & $\begin{array}{l}\text { Level of Living Survey (1973, } \\
80,90 \text { ), all employed, aged } \\
18-60\end{array}$ & C & $\begin{array}{l}\text { non-parametric la- } \\
\text { bor supply }\end{array}$ & PL & & & {$[.04, .12$} & & & \\
\hline & Flood et al. (2004) & $\begin{array}{l}\text { Household Income Survey } \\
\text { (1993), aged 18-64 }\end{array}$ & D & $\mathrm{TU}, \mathrm{R}$; stigma of $\mathrm{W}$ & own calc. & .12 & & 0 & & -.017 & -.003 \\
\hline & Brink et al. (2007) & $\begin{array}{lr}\text { Longitudinal } & \text { Individual } \\
\text { Data, Income } & \text { Distribution } \\
\text { Survey, 1999 } & \end{array}$ & D & $\mathrm{TU}, \mathrm{R}$ & FASIT & .18 & .15 & .06 & 0 & & \\
\hline Switzerland & $\begin{array}{l}\text { Gerfin \& Leu } \\
(2003)\end{array}$ & $\begin{array}{l}\text { Swiss Income and Expendi- } \\
\text { ture Survey (1998) }\end{array}$ & D & $\begin{array}{l}\text { quadratic utility, } \\
\text { random preferences }\end{array}$ & $\begin{array}{l}\text { Tax model } \\
\text { for } \text { Basel- } \\
\text { Stadt }\end{array}$ & .56 & .36 & .03 & .01 & $-.06 /-.04$ & $-.001 / 0$ \\
\hline \multirow[t]{6}{*}{ UK } & $\begin{array}{l}\text { Arellano \& Meghir } \\
\text { (1992) }\end{array}$ & $\begin{array}{l}\text { British FES and LFS (1983), } \\
\text { aged 20-59, with pre-school } \\
\text { children (upper bound for all } \\
\text { children) }\end{array}$ & C & $\begin{array}{l}\mathrm{SL}+\mathrm{FC} \text {, search } \\
\text { costs, endogenous } \\
\text { wage and unearned } \\
\text { income (IV) }\end{array}$ & $\mathrm{PL}$ & {$[.29,71]$} & - & & & {$[-.13,-.40]$} & \\
\hline & $\begin{array}{l}\text { Arrufat \& Zabalza } \\
(1986)\end{array}$ & $\begin{array}{l}\text { British General Household } \\
\text { Survey (1974), aged <60 }\end{array}$ & C & $\begin{array}{l}\text { CES utility based } \\
\text { labor supply, } \mathrm{R}\end{array}$ & PL & {$[.62-2.03]$} & 1.41 & & & $-.2 /-.14$ & \\
\hline & $\begin{array}{l}\text { Blundell \& Walker } \\
\text { (1986) }\end{array}$ & $\begin{array}{l}\text { FES (1980), all employed, } \\
\text { aged 18-59 }\end{array}$ & $\mathrm{C}$ & $\begin{array}{l}\text { Gorman polar form } \\
\text { and translog hours, } \\
\mathrm{R}\end{array}$ & PL & & & .024 & & & -.287 \\
\hline & $\begin{array}{l}\text { Blundell et al. } \\
\text { (1987) }\end{array}$ & FES (1981), aged 16-60 & $\mathrm{T} / \mathrm{H}$ & $\begin{array}{l}\text { non-linear labor } \\
\text { supply, unemploy- } \\
\text { ment risk }\end{array}$ & own calc. & & {$[.0,408]$} & & & & \\
\hline & $\begin{array}{l}\text { Blundell } \\
\text { (1998) }\end{array}$ & $\begin{array}{l}\text { FES (1978-92), 20-50, young } \\
\text { children (lower bound if no } \\
\text { child) }\end{array}$ & $\mathrm{C}$ & generalized LES, R & PL & {$[.13, .37] @$} & - & & & {$[-.19,0] @$} & \\
\hline & $\begin{array}{l}\text { Blundell } \\
(2000)\end{array}$ & $\begin{array}{l}\text { Family Resources Survey } \\
(1994-96)\end{array}$ & D & $\mathrm{QU}+\mathrm{FC}, \mathrm{R}, \mathrm{W}$ & TAXBEN & {$[.11-.17]$} & & & & & \\
\hline
\end{tabular}

Data: Income Distribution Survey (IDS), Household Budget Survey (HBS), Socio Economic Panel (SOEP), Family Expenditure Survey (FES), Labor Force Survey (LFS), EU Statistics on Income and Living Conditions (SILC). For Germany: West (W), East (E). Model: C = continuous labor supply (Hausman 1981 type); $\mathrm{T}$ = tobit model; $\mathrm{D}=$ discrete-choice model (van Soest 1995 type); A = estimation of joint distributions of wage and hours (sets of hour-wage opportunities vary across individuals); $\mathrm{H}=$ double hurdle model (labor supply and risk of unemployment). Specification: for Hausman model, labor supply is either linear (LL), quadratic (QL) or semi-log (SL); in discrete-choice models, utility is either quadratic (QU), translog (TU) or generalized Stone-Geary (GU); random preferences are sometimes accounted for (R) as well additional flexibility, either through fixed costs (FC) or part-time dummies (PTD). Models are male-chauvinistic (M) or account for joint decision in couples (J). Welfare programme participation (W). Childcare costs (CC). Tax-benefit: Hausman model often accounts for piecewise-linear budget set (PL) or more generally convex set (C); nonconvexities are sometimes accounted for (NC); differentiability of the budget function can be used (D); with discrete choice models, complete tax-benefit systems are simulated and we indicate the name of the microsimulation model when it is known. Elasticities: brackets indicate the range of values for all specifications (or the confidence interval when available). '@ indicates that the range also includes values for different age and number of children. Particip. = participation elasticities, corresponding to the increase in employment rate in \% points, except when indicated by * (in that case, \% increase in employment rate). For Spain, several additional references are cited in García and Suárez (2003) which point to similar elasticities as in the basic model in this study. 
Table 2: Labor Supply Elasticities in Europe: Single Individuals

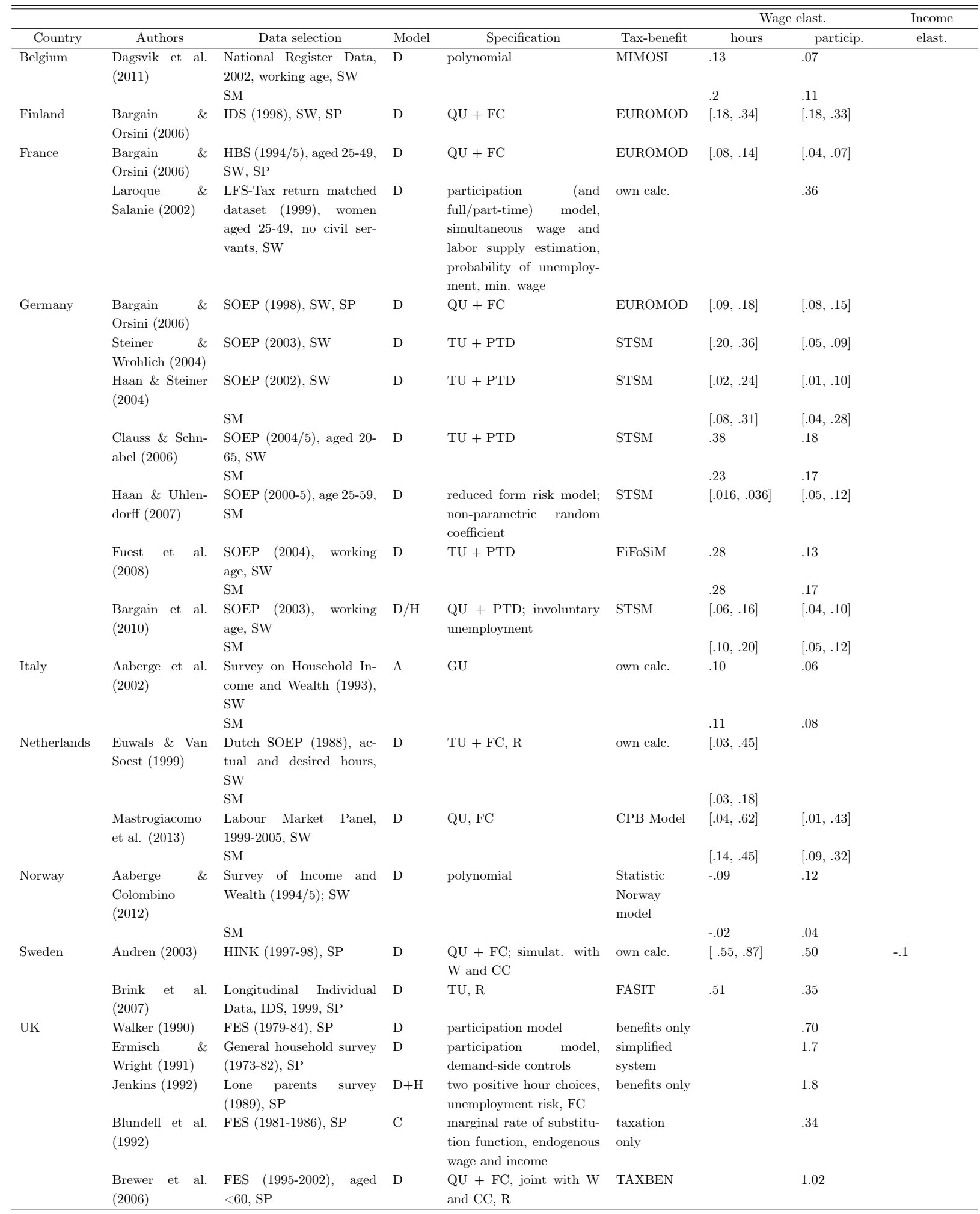

Data \& Selection: Income Distribution Survey (IDS), Household Budget Survey (HBS), Socio Economic Panel (SOEP), Family Expenditure Survey (FES), Labor Force Survey (LFS); Selection: single women (SW), single men (SM), single parents/mothers (SP). Model: C = continuous LS (Hausman 1981 type); T = tobit model; D = discrete model (van Soest, 1995 type); A = estimation of joint distributions of wage and hours (sets of hour-wage opportunities vary across individuals); $\mathrm{H}=$ double hurdle model (labor supply and risk of unemployment). Specification: for Hausman model, labor supply is either linear (LL), quadratic (QL) or semi-log (SL); in discrete-choice models, utility is either quadratic (QU), translog (TU) or generalized Stone-Geary (GU); random preferences (R); fixed costs (FC); welfare participation (W); childcare costs (CC). Tax-benefit: Hausman model often accounts for piecewise-linear budget set (PL) or more generally convex set (C); nonconvexities are sometimes accounted for (NC); differentiability of the budget function can be used (D); with discrete choice models, complete tax-benefit systems are simulated and we indicate the name of the microsimulation model when it is known. Elasticities: brackets indicate the range obtained in function of the specification at use, or the confidence interval when available. Particip. = participation elasticities, corresponding to the increase in employment rate in percentage points. 
Table 3: Labor Supply Elasticities for the US

\begin{tabular}{|c|c|c|c|c|c|c|c|c|c|}
\hline \multirow[b]{2}{*}{ Authors } & \multirow[b]{2}{*}{ Data selection } & \multirow[b]{2}{*}{ Model } & \multirow[b]{2}{*}{ Specification } & \multicolumn{2}{|c|}{ Female wage elast. } & \multicolumn{2}{|c|}{ Male wage elast. } & \multicolumn{2}{|c|}{ Income elast. } \\
\hline & & & & hours & particip. & hours & particip. & female & male \\
\hline Cogan (1981) & 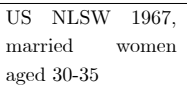 & $\mathrm{C}$ & $\begin{array}{l}\text { SL; reservation hours to } \\
\text { account for FC; no tax- } \\
\text { benefit }\end{array}$ & {$[.86,2.40]$} & & & & {$[.16, .66]$} & \\
\hline Hausman (1981) & $\begin{array}{l}\text { PSID 1975, married } \\
\text { women }\end{array}$ & $\mathrm{C}$ & LL, PL (C and NC: FC) & {$[.90,1.00]$} & & & & {$[-.13,-.12]$} & \\
\hline Triest (1990) & $\begin{array}{l}\text { PSID 1983, married } \\
\text { women, aged 25-55 }\end{array}$ & $\mathrm{C}$ & $\begin{array}{l}\text { LL; } \mathrm{C} \text { and PL; taxes and } \\
\text { benefits }\end{array}$ & {$[.03, .28]$} & & & & {$[-.15,-.19]$} & \\
\hline $\begin{array}{l}\text { MaCurdy et al. } \\
(1990)\end{array}$ & $\begin{array}{l}\text { PSID 1975: mar- } \\
\text { ried men, aged 25- } \\
55\end{array}$ & $\mathrm{C}$ & $\begin{array}{l}\text { LL; PL and D (reconvexi- } \\
\text { fied) budget set; taxes }\end{array}$ & & & {$[-.24, .03]$} & & -.01 & \\
\hline $\begin{array}{lll}\text { Dickert } & \text { et } & \text { al. } \\
(1995) & & \end{array}$ & $\begin{array}{l}\text { SIPP } 1990, \text { single } \\
\text { mothers, no assets }\end{array}$ & $\mathrm{D}$ & $\begin{array}{l}\text { joint program and labor } \\
\text { force participation }\end{array}$ & & .35 & & & & \\
\hline Pencavel (1998) & $\begin{array}{l}\text { CPS 1975-94, mar- } \\
\text { ried women, aged } \\
25-60\end{array}$ & $\mathrm{C}$ & Log-L; no tax-benefit & & {$[.77, .1 .80]$} & & & & \\
\hline & $\begin{array}{l}\text {, single women, } \\
\text { aged } 25-60\end{array}$ & & & {$[.77, .1 .80]$} & & & & & \\
\hline Hoynes (1996) & $\begin{array}{l}\text { SIPP panel, } 1984 \text {, } \\
\text { married men and } \\
\text { women with chil- } \\
\text { dren }\end{array}$ & D & $\begin{array}{l}\text { Stone-Geary; stigma from } \\
\text { AFDC; tax-benefit sys- } \\
\text { tem; FC }\end{array}$ & & & & & -.46 & -.12 \\
\hline $\begin{array}{l}\text { Keane and Moffitt } \\
(1998)\end{array}$ & $\begin{array}{l}1994 \text { SIPP, single } \\
\text { mothers, no assets }\end{array}$ & $\mathrm{D}$ & $\begin{array}{l}\text { joint labor supply and } \\
\text { welfare program partici- } \\
\text { pation; benefits but no tax }\end{array}$ & & .96 & & & & \\
\hline Pencavel (2002) & $\begin{array}{l}\text { CPS 1999, married } \\
\text { men }\end{array}$ & $\mathrm{C}$ & LL; no tax-benefit & & & {$[.12,25]$} & & & \\
\hline & $\begin{array}{l}\text { CPS } 1999, \text { single } \\
\text { men }\end{array}$ & & & & & {$[.12,25]$} & & & \\
\hline Devereux (2003) & $\begin{array}{l}\text { Census and PSID, } \\
\text { married men }\end{array}$ & $\mathrm{C}$ & Log-L, no tax-benefit & & & {$[-.022, .017]$} & {$[-.061, .001]$} & & \\
\hline Devereux (2004) & $\begin{array}{l}\text { single men } \\
\text { PUMS 1980,1990, } \\
\text { married couples } \\
\text { (participating men) }\end{array}$ & $\mathrm{C}$ & Log-L, no tax-benefit & {$[.17,38]$} & & $\begin{array}{l}{[-.022, .017]} \\
{[.00, .07]}\end{array}$ & {$[-.061, .001]$} & & \\
\hline $\begin{array}{l}\text { Eissa \& Hoynes } \\
(2004)\end{array}$ & $\begin{array}{l}\text { CPS } 1985 \text { to } 1997 \text {, } \\
\text { less educated mar- } \\
\text { ried couples with } \\
\text { children }\end{array}$ & D & $\begin{array}{l}\text { Participation Probit, joint } \\
\text { estimation }\end{array}$ & & .27 & & .03 & -.039 & -.007 \\
\hline $\begin{array}{l}\text { Blau \& Kahn } \\
(2007)\end{array}$ & $\begin{array}{l}\text { CPS } 1980 \text {, married } \\
\text { men and women } \\
\text { age } 25-54\end{array}$ & $\mathrm{C}$ & Log-L & {$[.77,88]$} & & {$[.01, .07]$} & & .004 & .001 \\
\hline & CPS 1990 & $\mathrm{C}$ & Log-L & {$[.58, .64]$} & & {$[.10, .14]$} & & .002 & .002 \\
\hline & CPS 2000 & $\mathrm{C}$ & Log-L & {$[.36,41]$} & & {$[.04, .10]$} & & .001 & .002 \\
\hline Heim (2007) & $\begin{array}{l}\text { CPS, 1979-2003, } \\
\text { married women }\end{array}$ & & $\begin{array}{l}\text { SL, participation, some } \\
\text { account for tax }\end{array}$ & $\begin{array}{l}.36(1979) \text { to } \\
.14(2003)\end{array}$ & $\begin{array}{l}.66(1979) \text { to } \\
.03(2003)\end{array}$ & & & $\begin{array}{l}-.05(1979) \text { to }- \\
.015(2003)\end{array}$ & \\
\hline Heim (2009) & PSID 2001, couples & & $\begin{array}{l}\text { quadratic utility with con- } \\
\text { tinuous labor supply, J, } \\
\text { FC, R }\end{array}$ & {$[.24, .33]$} & {$[.07, .18]$} & {$[.04, .07]$} & {$[.00, .003]$} & {$[-.007,-.006]$} & -.0007 \\
\hline Bishop et al. (2009) & $\begin{array}{l}\text { CPS, 1979-2003, } \\
\text { sing. women }\end{array}$ & & $\begin{array}{l}\text { SL, participation, some } \\
\text { account for tax }\end{array}$ & $\begin{array}{l}.14(1979) \text { to } \\
-.03(2003)\end{array}$ & $\begin{array}{l}.28(1979) \text { to } \\
.22(2003)\end{array}$ & & & $\begin{array}{l}-.014(1979) \text { to }- \\
.019(2003)\end{array}$ & \\
\hline
\end{tabular}

Data: Current Population Survey (CPS), National Longitudinal Surveys of Young Women and Mature Women (NLSW), Panel Study on Incom Dynamics (PSID), Public Use Microdata Sample (PUMS), Survey of Income and Program Participation (SIPP). Model: C= continuous labor supply (Hausman 1981 type); $\mathrm{D}$ = discrete-choice model (often a simple participation probit). Specification: Hausman labor supply is either linear (LL), log-linear (Log-L) or semi-log (SL); random preferences are sometimes accounted for (R) as well as fixed costs (FC). Models sometimes account for piecewise-linear budget set (PL) or more generally convex set (C) or nonconvexities (NC), and differentiable budget constraint (D). Elasticities: brackets indicate ranges of values over different specifications, or reported confidence intervals. Participation elasticities ("particip"): increase in employ. rate in $\%$ points. 
Table 4: Meta Regression of Married Women's Wage-Elasticities

\begin{tabular}{llllll}
\hline \hline Model & All elasticities & $\begin{array}{c}\text { Participation } \\
\text { elasticities }\end{array}$ & Hour elasticities & Without the US & All years \\
\hline year & $-0.013 * * *$ & $-0.012 *$ & $-0.012 *$ & $-0.013 * *$ & $-0.024 * * *$ \\
discrete model & $(.005)$ & $(.007)$ & $(.006)$ & $(.005)$ & $(.004)$ \\
& 0.013 & 0.170 & -0.007 & 0.043 & -0.012 \\
desired hours & $(.079)$ & $(.251)$ & $(.098)$ & $(.090)$ & $(.089)$ \\
& $0.185 * *$ & 0.086 & $0.237 * *$ & $0.177 * *$ & 0.121 \\
joint decision & $(.079)$ & $(.114)$ & $(.106)$ & $(.083)$ & $(.095)$ \\
fixed cost \# & -0.026 & -0.087 & 0.024 & -0.013 & 0.008 \\
& $(.062)$ & $(.085)$ & $(.088)$ & $(.067)$ & $(.071)$ \\
US & 0.025 & -0.024 & 0.069 & 0.014 & 0.041 \\
& $(.057)$ & $(.074)$ & $(.082)$ & $(.060)$ & $(.070)$ \\
constant & -0.045 & -0.083 & 0.006 & & -0.046 \\
& $(.084)$ & $(.150)$ & $(.108)$ & & $(.083)$ \\
Nb of observations & $0.462 * * *$ & 0.323 & $0.454 * * *$ & $0.439 * * *$ & $1.025 * * *$ \\
R2 & $(.079)$ & $(.283)$ & $(.089)$ & $(.085)$ & $(.096)$ \\
\hline Note: & 75 & 32 & 43 & 67 & 90 \\
\hline
\end{tabular}

Note: we regress elasticity values on modeling choices using estimates on data from 1985-2004, except the last column (1967-2004). \#: work cost specification in discrete models 